\title{
Tectonic evolution of the Dom Feliciano Belt in Southern Brazil: Geological relationships and U-Pb geochronology
}

\author{
Evolução tectônica do Cinturão Dom Feliciano no Sul do Brasil: \\ relações geológicas e geocronologia $\mathrm{U}-\mathrm{Pb}$
}

Ruy Paulo Philipp ${ }^{1 *}$, Marcio Martins Pimentel ${ }^{2}$, Farid Chemale Jr. ${ }^{3}$

\begin{abstract}
The Dom Feliciano Belt is an important Neoproterozoic to Cambrian orogenic complex, extending from eastern Uruguay to southern Brazil. It comprises a collage of oceanic domains and continental fragments developed between 900 and 540 Ma between the Rio de La Plata, Congo and Kalahari cratons. The integration of field and structural data with recent isotopic results has introduced new insights on the sources of the magmatism and sedimentary processes. This paper presents a review of the geochronological results combined with stratigraphic, structural and geochemical data. The evolution of the Dom Feliciano Belt involved three orogenic events known as the Passinho $(0.89-0.86 \mathrm{Ga})$, São Gabriel $(0.77$ $0.68 \mathrm{Ga})$ and Dom Feliciano $(0.65-0.54 \mathrm{Ga})$. The first two events involved the closure of the Charrua Ocean generating an intra-oceanic arc (Passinho) and, subsequently, an active continental margin arc (Sáo Gabriel). This ocean separated the continental areas represented by the Rio de la Plata Craton and the Nico Perez continental microplate. Closure of the Adamastor ocean resulted in an important collisional event between the Nico Perez Microplate/Rio de La Plata Craton and Kalahari and Congo cratons between 650 and $620 \mathrm{Ma}$, involving high T/intermediate $\mathrm{P}$ metamorphism. At this time of crustal thickening, the partition of the deformation controled the final evolution of the belt with important escape tectonics, responsible for nucleating crustal-scale transcurrent shear zones. These structures were deep and promoted the rise of mafic magmas, which, associated with high regional thermal gradient, lead to an important event of crustal reworking, responsible for the formation of the Pelotas Batholith. The orogenic collapse is represented by late magmatism of Pelotas Batholith and deposition of upper section of the Camaquá Basin. KEYWORDS: Rio de La Plata Craton; Nico Perez Microplate; Dom Feliciano Belt; U-Pb Geochronology; Orogeny.
\end{abstract}

RESUMO: O Cinturão Dom Feliciano, que se estende desde o leste do Uruguai até o sul do Brasil, representa um importante orógeno Neoproterozoico formado pela colagem de domínios oceânicos e fragmentos continentais entre os crátons Rio de La Plata, Congo e Kalahari. A integraçáo de dados de mapeamento geológico e estrutural com resultados isotópicos permitu estabelecer uma melhor compreensäo sobre as fontes de magmatismo e os processos de sedimentação. A evolução do Cinturão Dom Feliciano envolveu a superposição de três eventos orogênicos denominados Passinho (0.89 - 0.86 Ga), São Gabriel (0.77 - $0.68 \mathrm{Ga}) e$ Dom Feliciano $(0.65-0.54 \mathrm{Ga})$. Os dois primeiros eventos envolvem o fechamento do oceano Charrua com a geraçáo inicial de um arco intra-oceânico (Passinho) e, posteriormente, de um arco continental (São Gabriel). Esse oceano separava as áreas continentais representadas pelo cráton Rio de La Plata e a microplaca continental Nico Perez. No terceiro evento ocorreu fechamento do oceano Adamastor em decorrência da colisão entre os crátons Rio de La Plata e Kalahari entre 650 - $620 \mathrm{Ma}$, envolvendo condiçóes metamórficas de alta temperatura e pressão intermediária. Neste momento de grande espessamento crustal, a partição da deformação no cinturão controla a sua evolução final com a passagem para uma tectônica de escape, responsável pela nucleação de zonas de cisalhamento transcorrentes de escala crustal. Essas estruturas são profundas e promoveram a geração e a ascenção de magmas máficos, que, associados ao elevado gradiente térmico regional, induziram um extenso evento de retrabalhamento crustal, responsável pela formaçáo do Batólito Pelotas. O colapso do orógeno é representado pelo magmatismo tardio do batólito e pela formação das sequências superiores da Bacia do Camaquá.

PALAVRAS-CHAVE: Cráton Rio de La Plata; Microplaca Nico Perez; Cinturão Dom Feliciano; Geocronologia; U-Pb em Zircão; Orogênese.

\footnotetext{
${ }^{1}$ Institute of Geosciences, Universidade Federal do Rio Grande do Sul - UFRGS, Porto Alegre (RS), Brazil. E-mail: ruy.philipp@ufrgs.br 2Institute of Geosciences, Universidade de Brasília - UnB, Brasília (DF), Brazil. E-mail: pimentel@unb.br

${ }^{3}$ Postgraduate programme in Geology, Universidade do Vale do Rio dos Sinos - UNISINOS, São Leopoldo (RS), Brazil. E-mail: farid.chemale@gmail.com ${ }^{*}$ Corresponding author.
}

Manuscript ID: 20150016: Received: 07/13/2015. Approved: 02/08/2016. 


\section{INTRODUCTION}

The Mantiqueira orogenic system is of one of the main Neoproterozoic orogens formed during the assembly of West Gondwana. It comprises the Dom Feliciano (Uruguay and southern Brazil), Ribeira (Paraná, São Paulo, Minas Gerais and Rio de Janeiro states) and Araçuaí belts (Espírito Santo, eastern Minas Gerais and southern Bahia states) (e.g.: Heilbron \& Machado 2003). Its African counterpart includes the Saldania-Gariep, Damara, Kaoko and West Congo belts (Fig. 1). Several models have been presented to explain the tectonic evolution of this orogen and its role in the assemby of West Gondwana (e.g.: Chemale 2000, Cordani et al. 2003, Basei et al. 2008). The Mantiqueira Province is a NE-SW mobile belt running parallel to the southern and eastern coast of Brazil extending for more than $3,000 \mathrm{~km}$ from Bahia to Uruguay.
The Dom Feliciano Belt (DFB) formed during a longlived evolution of ca. $450 \mathrm{My}$, starting with the opening of the Charrua Ocean in the southwestern portion of Gondwana, at $950-900 \mathrm{Ma}$. The closure of this ocean and the collision of magmatic arcs occured between 770 and $680 \mathrm{Ma}$. This was followed by the closure of the Adamastor Ocean and the collision between the Nico Perez Microplate/Rio de La Plata Craton and the Kalahari Craton at the end of the Neoproterozoic. Three distinct events may be recognized:

1. the development of the Passinho Arc,

2. the development of the São Gabriel Arc, and

3. the formation of the Dom Feliciano Arc (Chemale Jr. et al. 1995, Chemale Jr. 2000, Saalmann et al. 2010).

In this paper, we present a review of the data on the $\mathrm{DFB}$ geological evolution, in particular the new $\mathrm{U}-\mathrm{Pb}$ geochronological data on igneous and metamorphic rocks and sedimentary

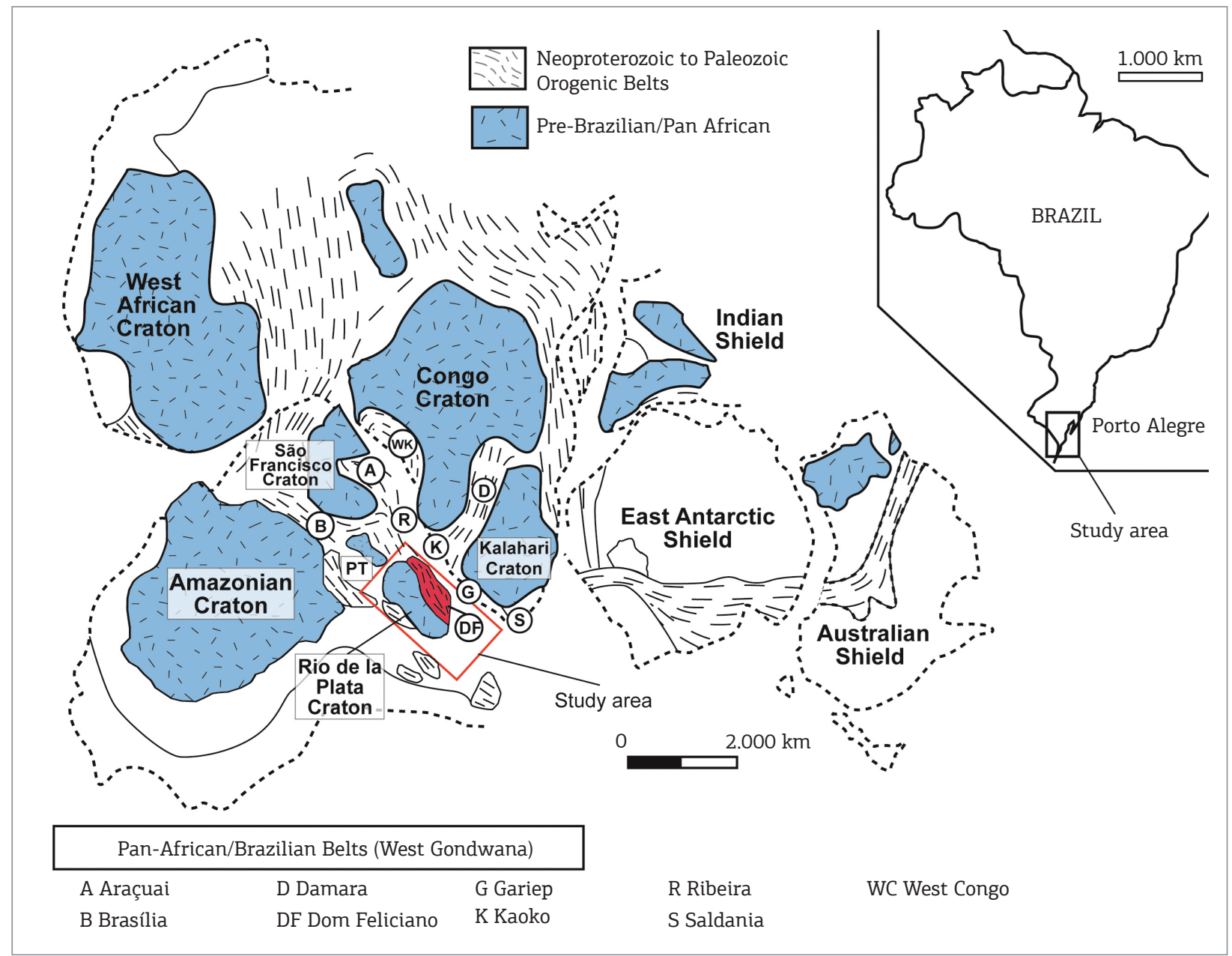

Figure 1. Southern portion of the Gondwana continent showing the main cratonic areas and of the Dom Feliciano belt and related belts of Africa. Cratons: $\mathrm{A}=$ Amazon, $\mathrm{C}=$ Congo, $\mathrm{K}=$ Kalahari, $\mathrm{LP}=$ Rio de la Plata, $\mathrm{PT}=\mathrm{Paraná}$, $\mathrm{SF}=$ São Francisco. Brasiliano-Pan-African Belts: $\mathrm{B}=$ Brasilia belt, DF $=$ Dom Feliciano belt, $\mathrm{G}=\mathrm{Gariep}$ belt, $\mathrm{R}=$ Ribeira belt, $\mathrm{K}=$ Kaoko belt, SG = São Gabriel Terrane. Modified from Rapela et al. (2011). 
provenance studies of the Precambrian terrains of the DFB, Nico Perez Microplate and Rio de La Plata Craton in RS. The present compilation includes, therefore, a historical review, starting with the pioneer Rb-Sr studies (Silva Filho 1984, Soliani Jr. 1986), and passing to the use of Pb-Pb and ID-TIMS U-Pb systematics (Machado et al. 1990, Babinski et al. 1996, 1997). More recently, the widespread use of the SHRIMP (Silva et al. 1997, 2000; Leite et al. 1998, 2000; Hartmann et al. 1999, 2000) and LA-ICP-MS techniques has produced abundant new isotopic data allowing significant progress to the understanding of tectonic processes in southern Brazil.

\section{METHODS}

This work is based mainly on a review of U-P and $\mathrm{Pb}-\mathrm{Pb}$ zircon geochronology available for the Precambrian terrains in southern Brazil. To assess the sources of magmas we used Rb-Sr, Sm-Nd and some Lu-Hf and $\delta^{18} \mathrm{O}$ data. The interpretation of geochronological and isotopic data was then combined with a review of field geological data produced by various regional geological mapping projects.

The magmatic crystallization ages are more abundant and were predominantly obtained by the Rb-Sr, U-Pb SHRIMP and LA-ICPMS methods. Metamoprhic ages were obtained by dating of zircon and titanite by $\mathrm{U}-\mathrm{Pb}$ method, of whole rock and mineral by Rb-Sr, Sm-Nd and Ar-Ar isotope methods, and of monazite from metapelites by EMPA. The U-Pb zircon data also include provenance studies of metavolcano-sedimentary complexes, including a total of 1,338 zircon grains analysed, of which 662 remain unpublished. Data used in the present review are presented in Figure 2.

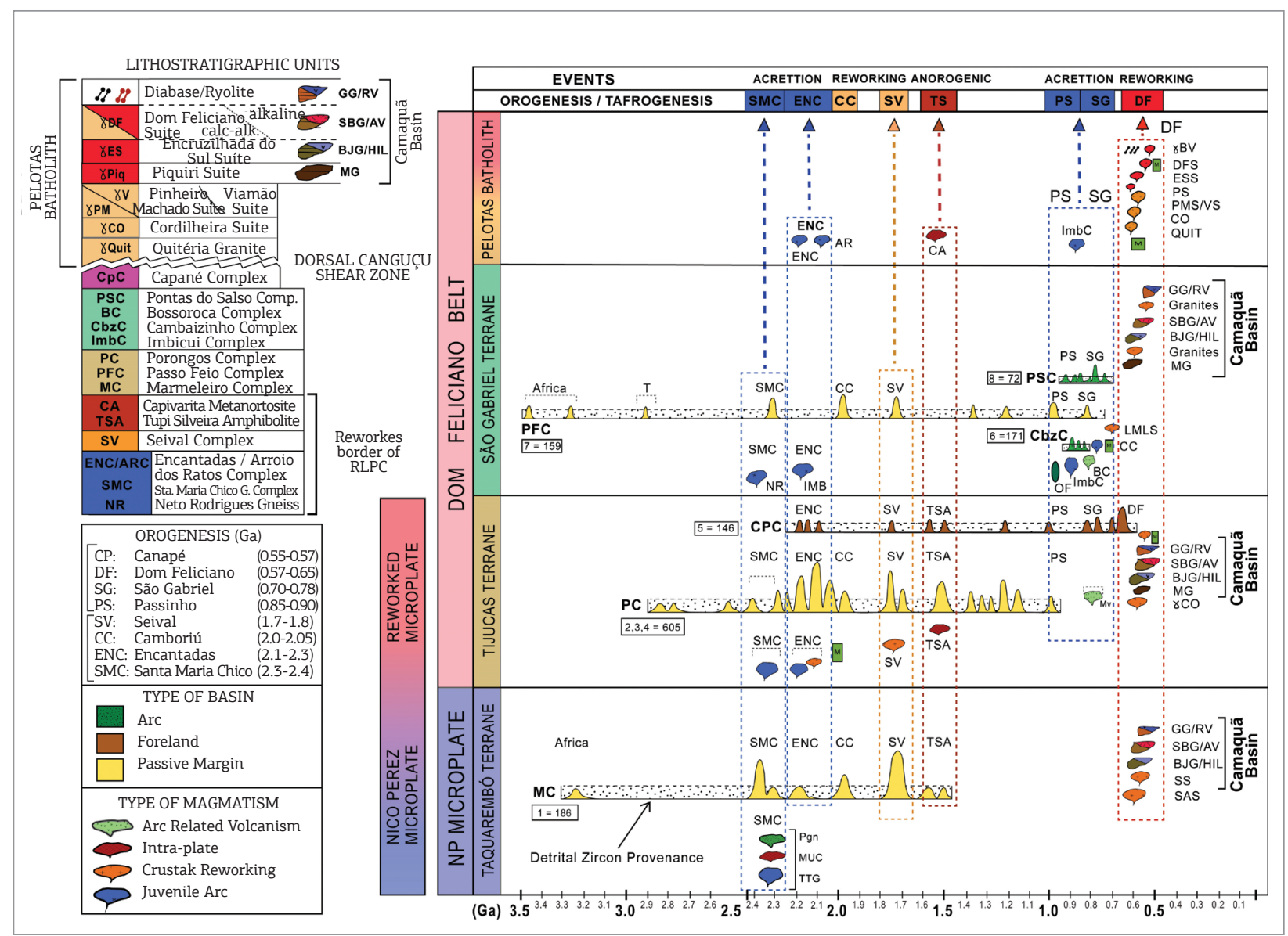

Figure 2. Distribution of the main lithotectonic units, events and tectonic processes in each terrane of the Dom Feliciano Belt and Taquarembó Terrane based on geochronological data, composition of the magmas, type of basin and orogenic events. The horizontal bars present the detrital zircon data in metasedimentary complexes. 1 - Unpublished data, 2 - Hartmann et al. (2004), 3 - Gruber et al. (2011), 4 - Pertile et al. (2015a), 5 - Pertile et al. (2015b), 6 - Lena et al. (2014), 7 - Lopes et al. (2015) and 8 - Vedana et al. (2016). Camaquã Basin legend: MG - Maricá Group, BJG/HIL - Bom Jardim Group/Hilário Andesite, SBG/AV - Santa Barbara Group/Acampamento Velho Rhyolite and GG/RV - Guaritas Group/Rodeio Velho Andesite. 


\section{GEOTECTONIC CONTEXT}

The southern Brazilian Shield comprises Paleo-, Meso- and Neoproterozoic tectono-stratigraphic units. The geology of this area consists of fragments of the Nico Perez Terrane (Oyhantçabal et al. 2011; Rapela et al. 2011) composed of Paleoproterozoic, Mesoproterozoic and Neoproterozoic metamorphic and granitic rocks, surrounded by Neoproterozoic associations of the DFB (Fig. 1).

The DFB is the southern segment of the Mantiqueira Province, and represents a crustal segment strongly deformed and migmatized between ca. 650 and $620 \mathrm{Ma}$ (eg.: Fernandes et al. 1992, Chemale et al. 1995, Basei et al. 2011, Bitencourt \& Nardi 2000, Philipp \& Machado 2005, Saalmann et al. 2005, 2006, 2010, Philipp et al. 2013, 2016a, Hartmann et al. 1999, 2000, 2011, Chemale Jr. et al. 2012). Remnants of older continental crust are represented by septa exposed in Santa Catarina (Hartmann et al. 2000, Basei et al. 2008), Rio Grande do Sul (Philipp \& Machado, 2005, Philipp et al. 2008, Hartmann et al. 2008, 2011), and Uruguay (Hartmann et al. 2002, Oyhantçabal et al. 2011).

The DFB is divided from west to east in:

1. São Gabriel Terrane,

2. Tijucas Terrane,

3. Florianópolis-Pelotas-Aigua batholiths,
4. Rocha and Punta del Este terranes (Fig. 3).

The belt comprises rock units developed during three major orogenic events: the Passinho (890 - $860 \mathrm{Ma})$, São Gabriel (770 - 680 Ma) and the Dom Feliciano (650 - $540 \mathrm{Ma})$ (e.g.: Chemale Jr. 2000, Hartmann et al. 2007, Saalmann et al. 2010, Philipp et al. 2014).

The relationships between the units of Rio de La Plata Craton (RLPC), Nico Perez Microplate (NPM) and Dom Feliciano Belt (DFB) are shown in Figure 2, in which a combination of information including the time relationships between lithostratigraphic and geotectonic units and time, $\mathrm{U}-\mathrm{Pb}$ and $\mathrm{Pb}-\mathrm{Pb}$ geochronology (crystallization, metamorphic ages and detrital zircon provenance in metasediments), geochemistry, and main orogenic cycles are presented. The geochronological data indicate three main Neoproterozoic orogenic events:

1. initial crustal accretion phase with juvenile magmatism, between ca. 890 and 860 ,

2. continental arc magmatism and accretion between 770 and $680 \mathrm{Ma}$, and

3. collisional metamorphism between 650 and $620 \mathrm{Ma}$ and a main magmatic phase between ca. 650 and $550 \mathrm{Ma}$, with intense crustal anatexis promoted by the injection of mantle magmas.

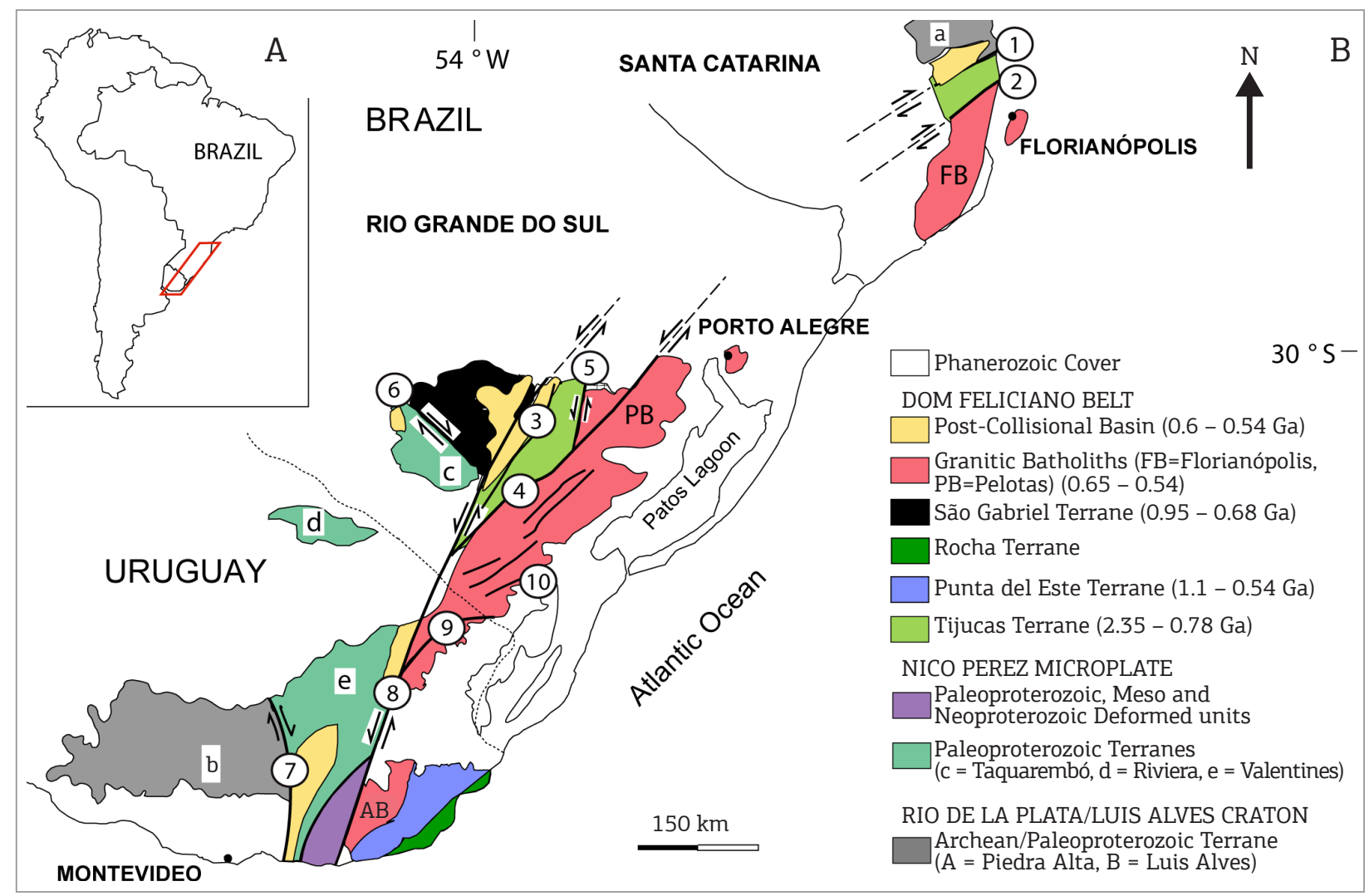

Figure 3. Geological map of the southern Brazilian and Uruguay shields (modified after Oyhantçabal et al. 2011, Rapela et al. 2011). Ductile Shear Zones: 1 - Itajai-Perimbó, 2 - Major Gercino, 3 - Caçapava do Sul, 4 - Dorsal de Canguçu, 5 Passo do Marinheiro, 6 - Ibaré, 7 - Sarandí del Yí, 8 - Sierra Ballena, 9 - Cerro Amaro, 10 - Arroio Grande. 
In some areas a younger regional metamorphic event (570 $560 \mathrm{Ma}$ ) associated with transcurrent shear zones is recognized.

The fragments of the Nico Perez Terrane (Oyhantçabal et al. 2011, Rapela et al. 2011) and Encantadas Microplate (Chemale Jr. 2000) occur as "basement inliers" in all geotectonic units of the DFB and are represented by Paleoproterozoic gneisses. The Paleoproterozoic rocks comprise associations formed in three main events:

1. the Santa Maria Chico (Siderian, 2.4-2.35 Ga),

2. the Encantadas (Rhyacian, 2.2-2.0 Ga), and

3. the Seival event (Statherian 1.8-1.7 Ga).

After that, the continental crust in southern Brazil experienced a period of tectonic quiescence which was marked by the emplacement of basic-ultrabasic complexes of Callymian age (1.57-1.55 Ga), represented by the Capivarita meta-anortosite (Chemale Jr. et al. 2011) and by the Tupi Silveira Amphibolite (Camozzato et al. 2013).

The Taquarembó Terrane (TT) is located in the southwestern portion of the shield and represents the largest exposed fragment of the Nico Perez Terrane (Fig. 4). The TT comprises the Paleoproterozoic Santa Maria Chico Granulitic Complex which is intruded by Neoproterozoic granites and covered by the volcano-sedimentary sequence of the Camaquã Basin.

\section{GEOTECTONIC UNITS OF THE DOM FELICIANO BELT}

\section{São Gabriel Terrane}

The São Gabriel Terrane (SGT) forms the western portion of the DFB and has an elongated shape in the $\mathrm{N} 20-30^{\circ} \mathrm{E}$ direction, underlying an area of approximately $110 \times 60 \mathrm{~km}$ (Fig. 3). This region is covered in the west and north by the Phanerozoic units of the Paraná Basin, and is limited to the south by the $\mathrm{N} 70 \mathrm{~W}-\mathrm{S} 70^{\circ} \mathrm{E}$ trending Ibaré Shear Zone (ISZ) and to the east by the Caçapava do Sul Shear Zone (CSSZ). Geophysical modelling of the Caçapava do Sul lineament shows that this structure is deep-seated and may be interpreted as the suture zone between the São Gabriel and Tijucas terranes (Chemale Jr. 2000 and references therein). The SGT consists of remanents of ophiolitic complexes and three Neoproterozoic magmatic arcs; the older is an intraoceanic arc (Passinho), and the younger represent active continental margins (São Gabriel and Dom Feliciano) (Fig. 3).

The units of the SGT are strongly controlled by N30 $40^{\circ} \mathrm{E}$ trending shear zones, which are rotated to the $\mathrm{N} 70^{\circ} \mathrm{W}$ direction by the Ibaré Shear Zone (ISZ) in the southern limit of the terrane. This tectonic linear structure is easily recognized by magnetic anomalies, as well by the elliptical shape of the plutonic bodies of the Neoproterozoic Seival Association.

The different rock units of the SGT may be grouped into three main petrotectonic associations:

1. the Palma Accretionary Prism,

2. Arc-related Associations and

3. the Seival volcano-sedimentary-plutonic association (Fig. 5).

The Palma Accretionary Prism is made of tectonic slabs of ophiolitic complexes, comprising magnesian schist, serpentinite and amphibolite, with subordinate metaperidotite, metagabbro and metapyroxenite. The Arc Association is composed of the Passinho and São Gabriel arc rocks, represented by metavolcano-sedimentary associations formed between ca. 0.89 and $0.68 \mathrm{Ga}$ (Machado et al. 1990, Babinski et al. 1996, Leite et al. 1998, Remus et al. 1999, Hartmann et al. 2011, Lena et al. 2014, Philipp et al. 2014). The Pontas do Salso Complex is a late-orogenic arc-related basin, younger than $0.68 \mathrm{Ga}$ and part of the São Gabriel Terrane (Vedana et al. 2016). These associations are in tectonic contact with passive margin metasedimentary association represented by the Passo Feio and Marmeleiro complexes. The Seival volcano-sedimentary-plutonic association formed between 0.61 and $0.54 \mathrm{Ga}$, representing the late to post-orogenic stages of the Dom Feliciano Orogeny (Chemale Jr., 2000).

\section{Palma Accretionary Prism}

\section{Ophiolitic Complexes}

The mafic-ultramafic complexes comprise amphibolite and metaultramafic rocks including serpentinized harzburgite, metapyroxenite, metagabbro, serpentinite and $\mathrm{Mg}$-rich schist with tholeiitic signature (Leite et al. 1998; Remus et al. 1999; Chemale Jr. 2000). Five major ophiolite complexes, Palma, Passo do Ivo, Cerro Mantiqueira, Cambaizinho and Arroio Lajeadinho occur elongated bodies parallel to regional structures (Figs. 5 and 6).

The metaultramafic rocks present $M_{1}$ assemblage comprising antophilite+forsterite+enstatite, defining conditions of medium to high grade with low pressure (Leite et al. 1998, Chemale Jr. 2000). Younger metamorphic events were accompanied by the formation of ductile shear zones which characterize the later regional deformation and mark the $\mathrm{M}_{2}$ greenschist facies metamorphism. The authors interpreted the amphibolite metamorphism $\left(M_{1}\right)$ and the late greenschist facies event $\left(M_{2}\right)$ as related to the São Gabriel and Dom Feliciano events, respectively. Relicts of olivine and spinels have chemical composition typical of ophiolitic rocks. U-Pb SHRIMP zircon ages for metasomatic albitites formed during low-temperature serpentinization of 


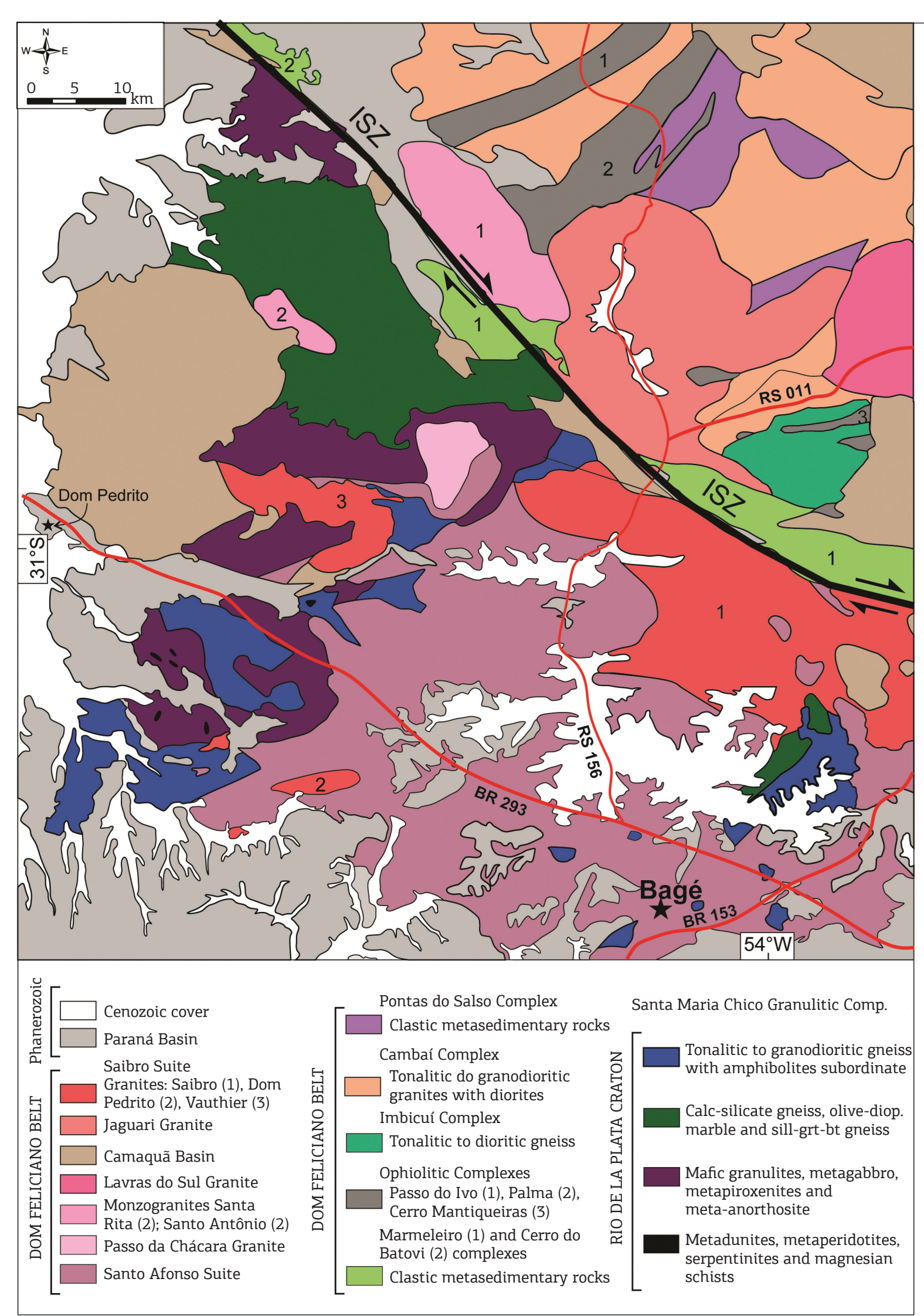

ISZ = Ibaré Shear Zone

Figure 4. Geological map of the Taquarembó Terrane (from Philipp et al., 2016a). 

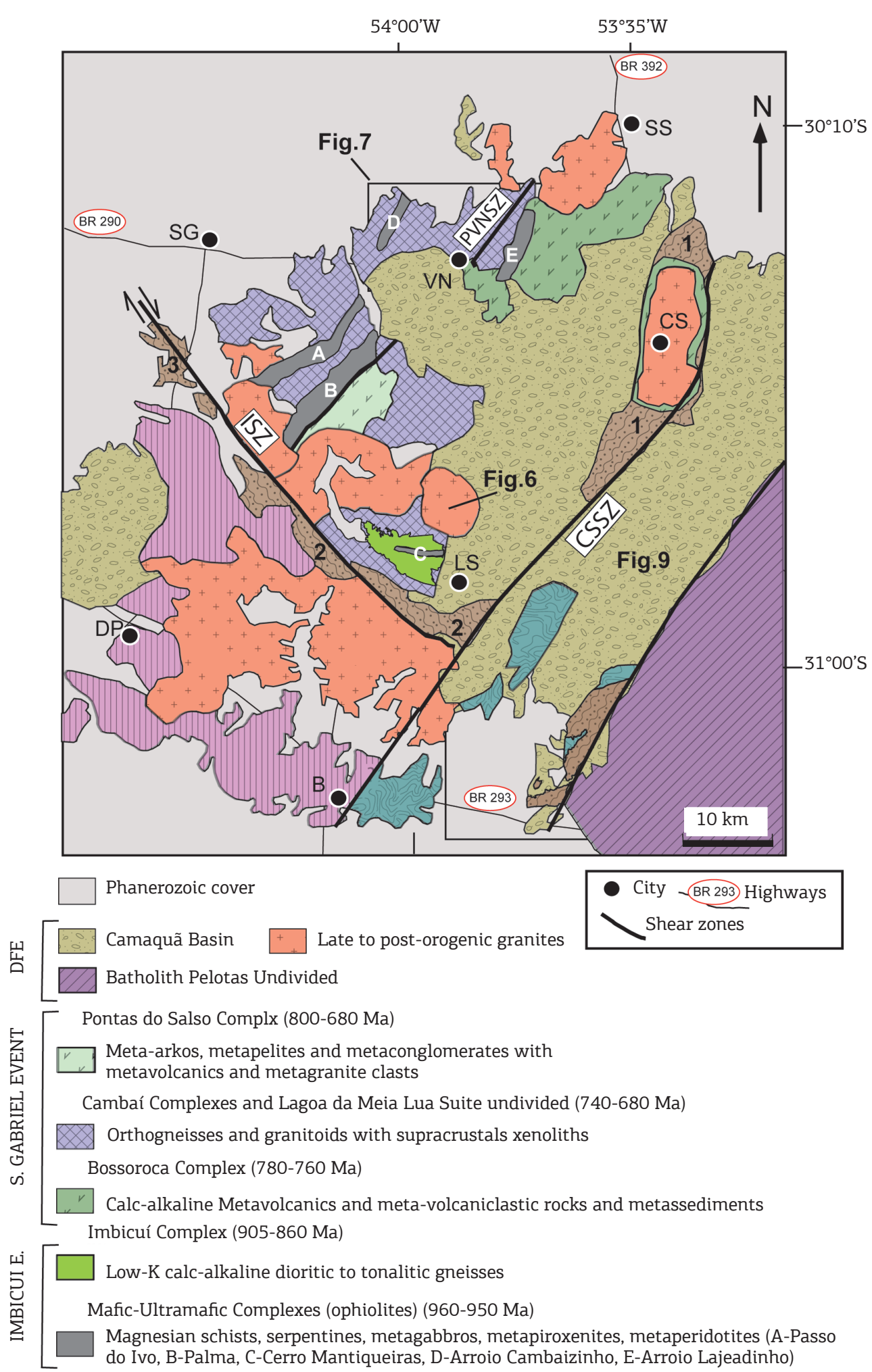

Passo Feio Complex (1), Arroio Marmeleiro Complex (2) and Coxilha do Batovi Complex (3)

Association of passive margin, metapelites, marbles, quartzites, calc-silicate schistsin

Paleoproterozoic Basement

Encantadas Complex (2.050-2.250 Ma)

II Santa Maria Chico Granulitic Complex (2.370-2.300 Ma)

Figure 5. Geological map of the São Gabriel Terrane. 
ultramafic rocks of the Cerro Mantiqueira and Ibaré ophiolites are $923 \pm 3 \mathrm{Ma}$ and $892 \pm 3 \mathrm{Ma}$, respectively, which are interpreted by Arena and Hartmann (2015) as the emplacement age of these ophiolites. Metamorphic rims dated at $787 \pm 13 \mathrm{Ma}$ were determined in the Cerro Mantiqueira ophiolite.

\section{Arc Associations}

\section{Passinho Arc}

The rocks of the Passinho Arc are exposed in the southern portion of the SGT in an area located south and north of the Cerro da Mantiqueira Ophiolite (Figs. 5 and 6). The arc rocks occur as an EW elongated belt and are represented by orthogneisses of the Imbicuí Complex. It includes tonalitic to trondhjemitic gneisses in the central portion, involved by diorite gneisses (Lusa et al. 2016) (Fig. 6). The gneisses present tholeiitic to low-K calc-alkaline chemical composition and have crystallization ages between ca. 890 and $860 \mathrm{Ma}$. Dioritic gneisses exposed to the south of the Cerro Mantiqueiras complex have SHRIMP U-Pb ages of $879 \pm$ $14 \mathrm{Ma}$ (Leite et al. 1998), and LA-ICPMS ages of $890 \pm 9 \mathrm{Ma}$ and $885 \pm 3 \mathrm{Ma}$ (Philipp et al. 2014; Lusa et al. 2016). They

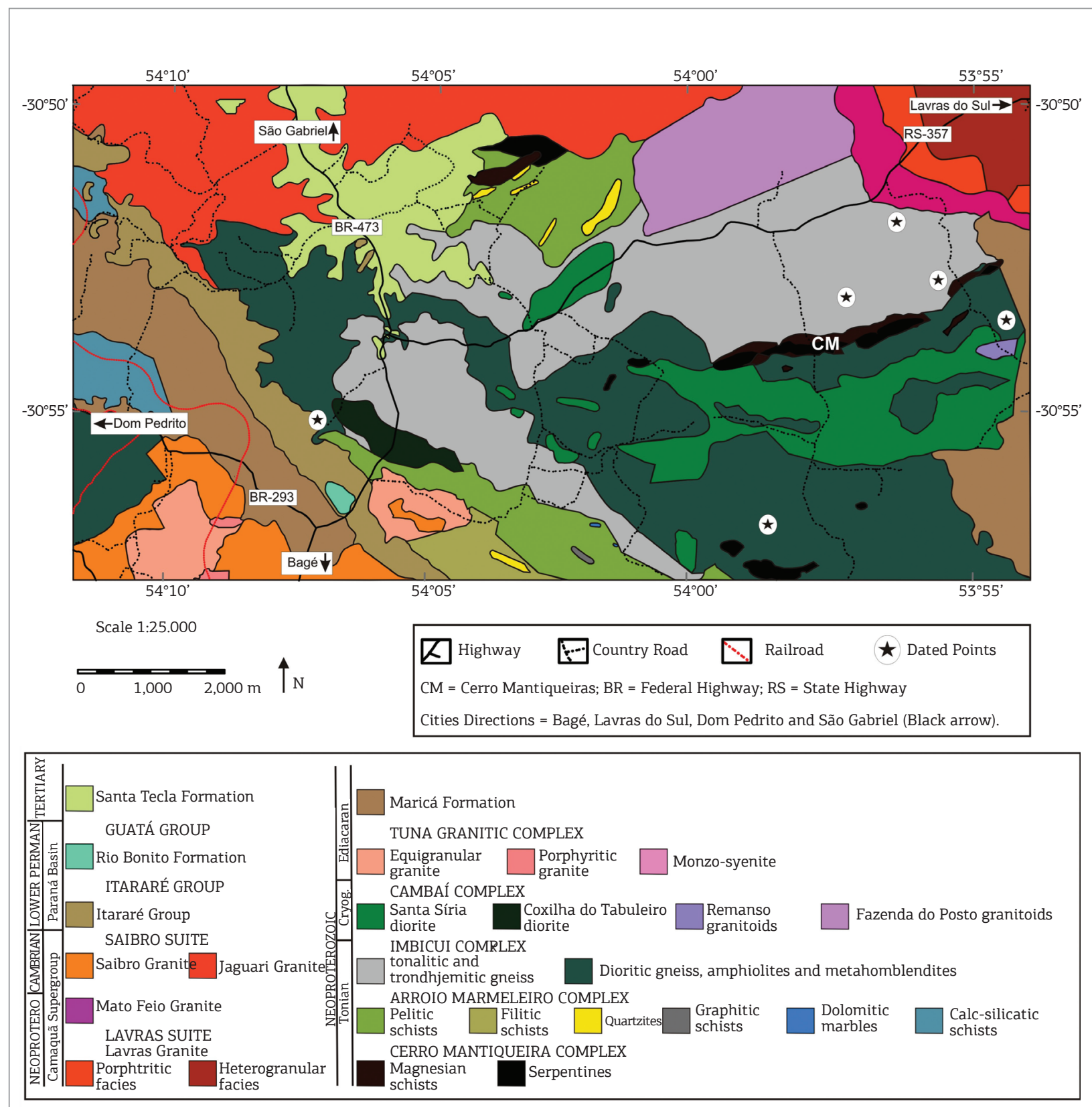

Figure 6. Geological map of the Cerro Mantiqueira region, south of Lavras do Sul (from Lusa et al. 2016). 
are intruded by diorites and tonalites related to the Cambaí Complex with U-Pb ages between 740 and $710 \mathrm{Ma}$ (Leite et al. 1998, Lusa et al. 2016). To the east, these units are covered by the sedimentary rocks of the Maricá Formation of the Camaquá Basin.

The regional metamorphism of the Imbicuí Complex is marked by the assemblage plagioclase + hornblende + biotite and plagioclase + hornblende + diopside, indicative of P-T conditions of the mid-to upper amphibolite facies, with low pressure. A retrograde metamorphic event is marked by a greenschist to lower amphibolite paragenesis formed of albite + actinolite/hornblende + chlorite + epidote + white mica.

\section{Sáo Gabriel Arc}

Rocks of the São Gabriel Arc are exposed in a large area extending from São Gabriel, Vila Nova do Sul and São Sepé, in the west, to Lavras do Sul, in the south (Fig. 5). The São Gabriel Arc consists of metavolcano-sedimentary rocks of the Bossoroca Complex, orthogneiss and metagranitic rocks of the Cambaí Complex, late- to post-collisional granites and diorites of the Lagoa da Meia Lua Suite, and mafic to ultramafic rocks of the Mata Grande Complex. These rocks are interlayered with the ophiolitic complexes and with metasedimentary rocks of the Cambaizinho and Passo Feio complexes, and are covered by the metasedimentary rocks of the Pontas do Salso Complex.

\section{Metavolcanic Rocks}

The Bossoroca Complex consists of Neoproterozoic metavolcano-sedimentary rocks including acid to intermediate metatuffs and metalapilli tuffs and lava flows (metadacites, meta-andesites and metabasalts), which are associated with metapelitic, carbonaceous and chemical metasediments (Machado et al. 1990, Remus et al. 1999; Gubert et al. 2016). Metavolcanoclastic rocks, pillowed metabasalts, amphibole schists and amphibolites exposed in the western part of the Passo Feio Complex may be correlated with the metavolcanic associations of the Bossoroca Complex, according to the existing petrographic and geochemical data. The metavolcanic rocks have low- to medium-K calc-alkaline composition. Machado et al. (1990) reported the TIMS U-Pb age of ca. $753 \mathrm{Ma}$ for a metadacite, which is identical to the U-Pb SHRIMP age of $756 \pm 14 \mathrm{Ma}$ reported by Remus et al. (1999) and U-Pb LA-ICP-MS of $767 \pm 3 \mathrm{Ma}$ and $765 \pm 10 \mathrm{Ma}$ reported by Gubert et al. (2016). Remus et al. (1999) and Hartmann et al. (2011) obtained ages of ca. $700 \mathrm{Ma}$ for the metamorphic event that affected this sequence.

\section{Metagranitic Rocks}

The Cambaí Complex (CC) is composed of two magmatic associations: (i) tonalitic, trondhjemitic and dioritic gneiss, and (ii) intrusive metatonalites, metagranodiorites and metadiorites
(Fig. 7). The paragneisses of the Cambaizinho Complex are either interlayered with or occur as xenoliths in the CC. Rocks of the $\mathrm{CC}$ are metaluminous, have mid- to high-K calc-alkaline chemical composition and are cut by undeformed intrusions of the Lagoa da Meia Lua Suite (Hartmann et al. 2011). The Cambaí gneisses yielded U-Pb SHRIMP and LA-ICP-MS zircon ages of ca. 740 and $720 \mathrm{Ma}$, interpreted by Hartmann et al. (2011) and Vedana et al. (2016) as the age of igneous crystallization. $\mathrm{U}-\mathrm{Pb}$ SHRIMP zircon ages of slightly deformed tonalites and diorites of the CC are between ca. 710 and $690 \mathrm{Ma}$ (Babinski et al. 1996, Hartmann et al. 2011), and those reported for tonalites and diorites in the Lavras do Sul region are in the range between 740 and $720 \mathrm{Ma}$ (Leite et al. 1998, Lusa et al. 2016). Rocks of the CC present positive initial $\varepsilon_{\mathrm{Nd}}$ values and low initial ${ }^{86} \mathrm{Sr} /{ }^{87} \mathrm{Sr}$ ratios (Saalmann et al. 2005), indicating juvenile nature of the original magmas (Babinski et al. 1996).

The Lagoa da Meia Lua Suite (LMLS) is made of tonalite-granodiorite to diorite forming $\mathrm{N} 20-30^{\circ} \mathrm{E}$ elongated bodies, concordant with the main ductile shear zones of the SGT. This suite includes the youngest magmatic rocks of the São Gabriel orogen and is intrusive into the Cambaizinho and Cambaí complexes (Fig. 7). The LMLS represents a late to post-orogenic intrusive event, including the Capivara Diorite, the Sanga do Jobim Granodiorite, the Cerca de Pedra Granodiorite and the Buriti Tonalite (Garavaglia et al., 2002 Hartmann et al. 2011 and references therein). The SHRIMP U-Pb zircon ages indicate that the granitoid emplacement occurred between 700 and $680 \mathrm{Ma}$, including ages of $703 \pm 7 \mathrm{Ma}$ for the Buriti Tonalite, $704 \pm 3 \mathrm{Ma}$ for the Santa Zélia Granite, $690 \pm 2$ Ma for the BR-290 tonalite, $694 \pm 5 \mathrm{Ma}$ for the BR-290 trondhjemite, $682 \pm 2 \mathrm{Ma}$ for the Cerca de Pedra Granodiorite, and $680 \pm 2$ Ma for the Sanga do Jobim Granodiorite (Hartmann et al. 2011).

The Mata Grande and the Pedra Pretas complexes are the two main mafic plutonic bodies of the Lagoa da Meia Lua Suite. The Mata Grande is a layered intrusion composed by gabbro-peridotite and other cumulate rock units dated by LA-ICPMS U-Pb zircon method at $668 \pm 3 \mathrm{Ma}$ (Simóes et al. 2014).

The metasedimentary rocks of the Pontas do Salso Complex are exposed in the southeastern portion of the SGT. Metaarkoses are dominant, with subordinate lenses of conglomeratic meta-arkoses and phyllites. The metaconglomerates and meta-sandstones are immature with clasts of metavolcanic and granitic rocks with andesitic to dacitic composition and medium-K calc-alkaline affinity (Vedana et al. 2016). Petrographic and geochemical data indicate that the sources of the metasedimentary rocks were metavolcanic and metagranitic rocks of the Passinho and São Gabriel arcs. LA-ICP-MS detrital zircon provenance data for a meta-arkoses and muscovite phyllite indicated that the sources of the complex have ages 
between 900 and $680 \mathrm{Ma}$ (Vedana et al. 2016). The youngest ages suggest that the complex represents a late- to post-orogenic basin and the collapse of the São Gabriel Arc.

\section{Metasedimentary Complexes}

The Cambaizinho and Passo Feio complexes together with the ophiolitic rocks are the oldest units of the SGT. Both supracrustal units occur as km-long elongated strips, as well as metric-decametric xenoliths and roof pendants, in the Cambaí Complex metagranitoids and in the granites of the LMLS (Hartmann et al. 2011).

The Cambaizinho Complex (CbC) (Lena et al. 2014) comprises metapelitic gneisses with intercalations of calc-silicate rocks, marbles and impure quartzite. Metamorphic paragenesis as biotite + garnet + staurolite and plagioclase + quartz + diopside + grossular indicates metamorphism in mid- to upper amphibolite facies conditions. Sm-Nd isotope data presented by Saalmann et al. (2005) indicate that the original sediments of the Cambaizinho Complex derived from the erosion of juvenile rocks of the Passinho and São Gabriel arcs. Lena et al. (2014) presented the results of combined SHRIMP and LA-ICP-MS $\mathrm{U}-\mathrm{Pb}$ ages of detrital zircon grains from the metasedimentary rocks of the Cambaizinho Complex. Igneous ages range from 840 to $700 \mathrm{Ma}$, with a peak around 750 and $700 \mathrm{Ma}$, suggesting that the tectonic setting of the original sediments was part of a fore-arc or back-arc basin. The $\delta^{18} \mathrm{O}$ values of the detrital zircon varied from +3.2 to $+9.6 \%$ and are grouped into three distinct groups of sediment sources. They point to a progressive evolution of the São Gabriel Terrane from an intraoceanic arc to a continental active margin.

The Passo Feio Complex (PFC) is exposed in the eastern part of the SGT and was defined as a sequence of metapelite, marble, calc-silicate rocks and quartzite, intercalated with amphibolite, metavolcanic/metavolcanoclastic rocks and magnesium schist (Figs. 3 and 5). The U-Pb SHRIMP zircon provenance work was carried out by Remus et al. (2000) in one sample from the northwestern part of the PFC, and show zircon grains ranging in age from Archean to Neoproterozoic. Based on U-Pb detrital zircon data of the Passo Feio Complex metasedimentary rocks, Lopes et al.

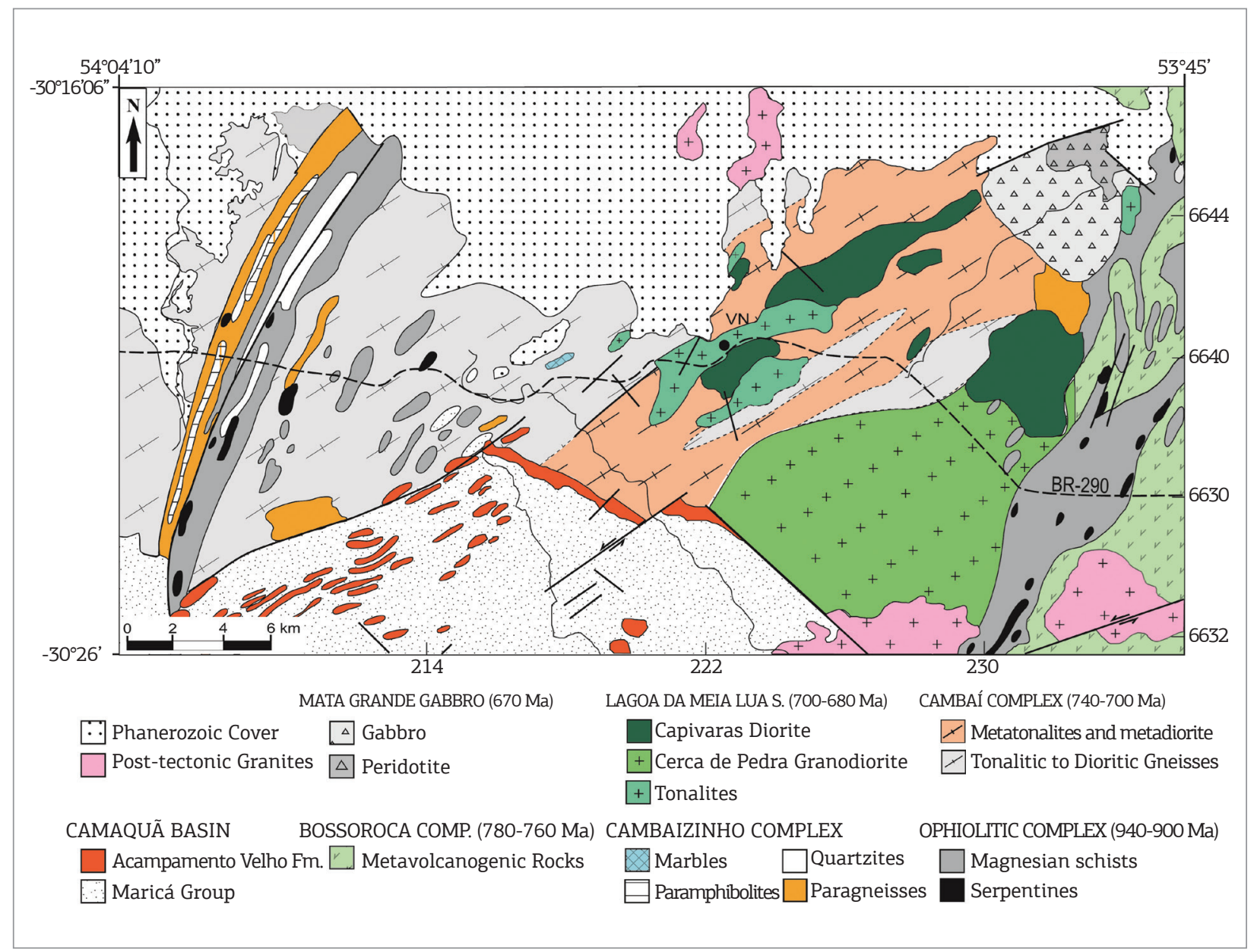

Figure 7. Geological map of the Vila Nova region (modified from Hartmann et al. 2011). 
(2015) recognized also zircon ages ranging from 0.803 to 3.637 Ga with Neo, Meso and Paleoproterozoic and Archean distribution pattern, suggesting that the PFC was originated from the erosion of complex continental sources.

\section{Tijucas Terrane}

The Tijucas Terrane (TjT) is elongated in the $\mathrm{N} 30-40^{\circ} \mathrm{E}$ direction, extending for $170 \mathrm{~km}$ with width between 15 and $30 \mathrm{~km}$ (Fig. 8). It is in tectonic contact with the SGT to the west along the Caçapava do Sul Shear Zone. The eastern boundary, with the Pelotas Batholith, is marked by the strike-slip Dorsal do Canguçu Shear Zone (e.g.: Fernandes et al. 1992, Philipp et al. 2003). The northeastern contact of the TjT with the Pelotas Batholith is affected by the Passo do Marinheiro Shear Zone. The TjT consists of:

1. a basement inlier made of Paleoproterozoic orthogneisses of the Encantadas and Vigia complexes,

2. Statherian Seival Metagranite,

3. Calymminian Tupi Silveira Amphibolite, and

4. Neoproterozoic metavolcanic and metasedimentary rocks of the Porongos Complex (Saalmann et al. 2005) (Fig. 8).

Basement orthogneisses are exposed in the core of largescale antiforms known as the Santana da Boa Vista Dome and as the Vigia Dome in the Hulha Negra region (Fig. 9).

\section{Basement Domes}

The Santana da Boa Vista and Vigia Domes are surrounded by metasedimentary and metavolcanic rocks of the Porongos Complex. The contact between the complexes is represented by a low-angle ductile shear zone marked by mylonites which obliterate the original stratigraphic relationships.

\section{Encantadas Complex}

The Encantadas Complex (EC) is a Paleoproterozoic (Siderian and Rhyacian) unit composed of dioritic, tonalitic and trondhjemitic gneisses with minor amphibolite and hornblende-rich metaultramafic rocks, where gneisses are metaluminous to slightly peraluminous, with medium-K calc-alkaline nature, representing a typical high-Al TTG association (Philipp et al. 2008, 2016b) (Fig. 8). This metamorphic complex is intruded by Rhyacian mylonitic monzoand syenogranitic gneisses (Philipp et al. 2008, 2016b).

The EC tonalitic gneisses have SHRIMP U-Pb crystallization zircon ages of $2.340 \mathrm{Ma}$, whereas intrusive monzogranitic to syenogranitic mylonitic gneisses present Rhyacian LA-ICP-MS U-Pb ages of 2.211 $\pm 17 \mathrm{Ma}$ and $2.210 \pm 16 \mathrm{Ma}$ (Philipp et al. 2016b). The gneiss was metamorphosed under upper amphibolite facies conditions during the Orosirian

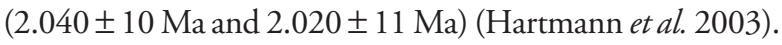
Zircon grains from the EC orthogneiss in the Hulha Negra and
Candiota regions display two LA-ICP-MS U-Pb age populations: (i) Siderian ages of ca 2.40 to $2.35 \mathrm{Ga}$ and (ii) Rhyacian ages, with values of ca $2.23 \mathrm{Ga}$ to $2.15 \mathrm{Ga}$ (Camozzato et al. 2013). In the Vigia Dome region, in Hulha Negra, the EC orthogneisses are intruded by the Seival Metagranite and by theTupi Silveira Amphibolite. The tonalitic gneisses of the EC have $\mathrm{U}-\mathrm{Pb}$ crystallization ages of $2.112 \pm 22 \mathrm{Ma}$ and $2.153 \pm$ $20 \mathrm{Ma}$, as well as a concordia age of $643 \pm 13 \mathrm{Ma}$ for metamorphic zircon grains (Camozzato et al. 2013).

\section{Vigia Complex}

The Vigia Complex (VC) is a Paleoproterozoic (Rhyacian) unit composed of dioritic, tonalitic and trondhjemitic gneisses with minor amphibolite exposed at the southern portion of the Tijucas Terrane (Camozzato et al. 2013) (Fig. 8). This metamorphic complex is intruded by the Seival Metagranite, an elongate NE-SW pluton of Sthaterian age that intrudes the VC in the southeastern portion of the Vigia Dome (Fig. 9). Geochemical data indicate that the VC gneisses are metaluminous to slightly peraluminous, with medium to high-K calc-alkaline nature, characterizing a high-Al TTG association (Camozzato et al. 2013).

The VC tonalitic gneisses have LA-ICP-MS crystallization zircon ages of $2.05-2.04 \mathrm{Ga}$ (Camozzato et al. 2013). In the Vigia Dome region, in Hulha Negra, the VC orthogneisses are intruded by the Seival Metagranite and by theTupi Silveira Amphibolite.

\section{Seival Metagranite}

The Seival Metagranite (SM) is a $40 \times 10 \mathrm{~km}$ pluton elongated in the $\mathrm{N} 30^{\circ} \mathrm{E}$ direction, intrusive into the $\mathrm{VC}$ gneiss in the southeastern portion of the Vigia Dome (Fig. 9). The metagranite has a monzogranite to granodiorite composition and present equigranular texture made of K-feldspar, plagioclase, quartz and biotite $(<5 \%)$. Geochemical data indicate high-K calc-alkaline composition, with metaluminous to slightly peraluminous nature, and trace element characteristics similar to those of evolved arc-related associations (Camozzato et al. 2013). Three samples of the SM were dated and yielded U-Pb LA-ICP-MS ages of $1.785 \pm 42 \mathrm{Ma}, 1.768 \pm 24 \mathrm{Ma}$ and $1.764 \pm$ $29 \mathrm{Ma}$, revealing, therefore, a previously unknown Statherian granitic magmatism in southern Brazil (Camozzato et al. 2013).

\section{Tupi Silveira Amphibolite}

The Tupi Silveira Amphibolite (TSA) crops out in the southern portion of the Vigia Dome, comprising two bodies about $1-2 \mathrm{~km}$ in length, elongated in the $\mathrm{N} 10^{\circ} \mathrm{E}$ and $\mathrm{N} 30^{\circ} \mathrm{E}$ directions (Fig. 9). The bodies are intrusive into the $\mathrm{VC}$ gneisses, although direct contact relationships have not been observed. The amphibolites present a regular and continuous banding of milimetric thickness and polygonal granoblastic texture defined by plagioclase, hornblende, garnet and rare 


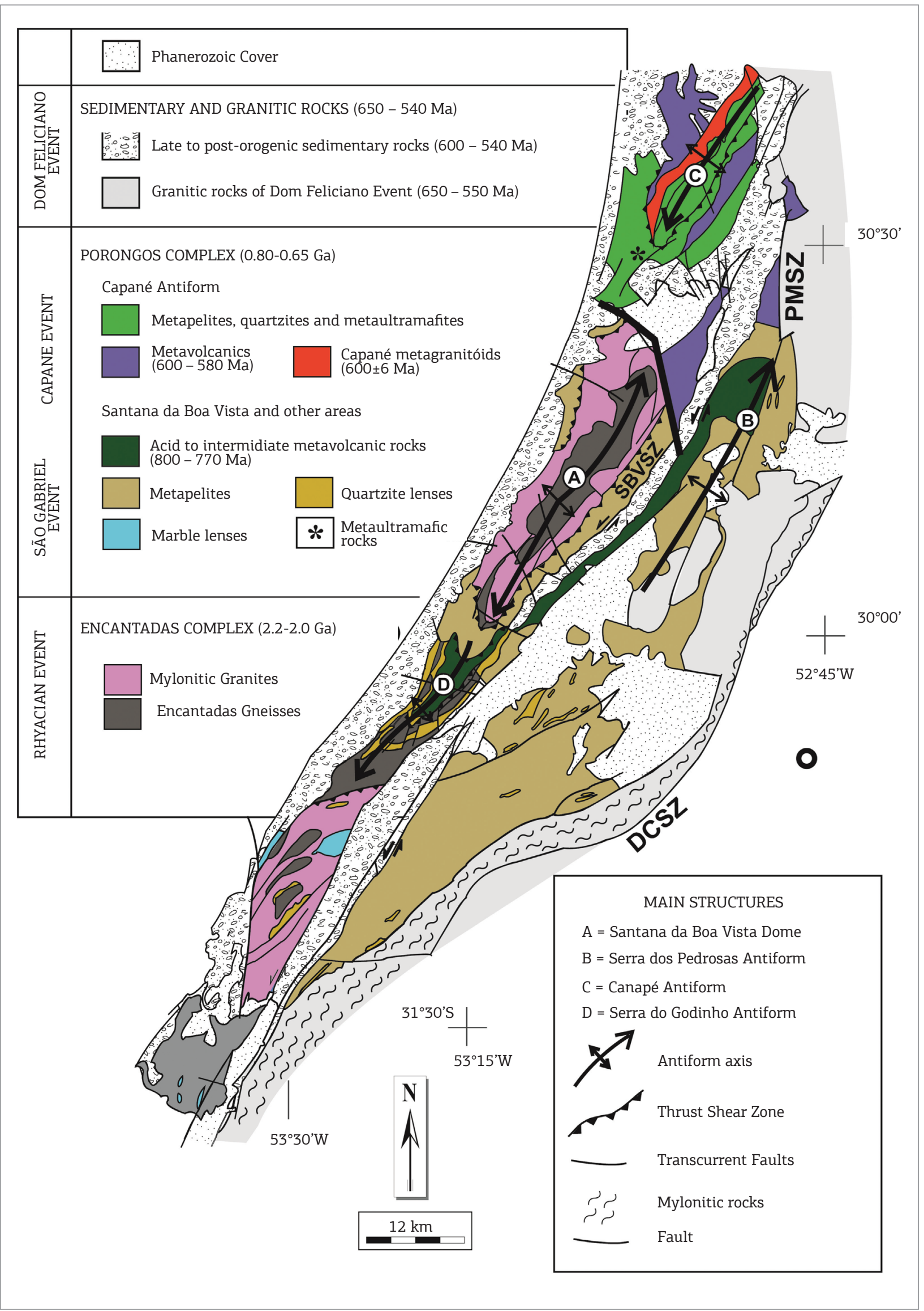

Figure 8. Geological map of the Santana da Boa Vista region (Philipp et al. 2016b). 
diopside. U-Pb age of one sample of the TSA revealed the crystallization age of $1.567 \pm 21 \mathrm{Ma}$ (Camozzato et al. 2013). This is similar to the $1.573 \pm 21 \mathrm{Ma}$ age of the Capivarita Anorthosite (Chemale Jr. et al. 2011). These units represent a Calymminian anorogenic magmatic event characterized by basic and ultrabasic layered complexes. After crystallization, both units were affected by collisional metamorphism under granulite facies, between ca. 650 and $620 \mathrm{Ma}$.

\section{Metavolcano-sedimentary complexes}

\section{Porongos Complex}

The Porongos Complex (PC) is a Neoproterozoic metavolcano-sedimentary sequence and one of the main units of the TjT (Fig. 3). The supracrustal succession comprises two sequences (Fig. 8). The south and southeastern sequence consists of a pile of quartzite, schists and marble lenses, interlayered with metarhyolites, metadacites and meta-andesites. The northern sequence is younger and consists of metapelites and quartzites intercalated with Ediacaran felsic metavolcanic rocks represented by finegrained crystal metatuffs and metadacites and intruded by alkaline granite (Saalmann et al. 2010). The metamorphism ranges from greenschist to amphibolite facies with intermediate pressure.

SHRIMP and LA-ICP-MS provenance studies have shown that metasedimentary rocks of the PC derived from two main sources. The metasedimentary rocks in the lower
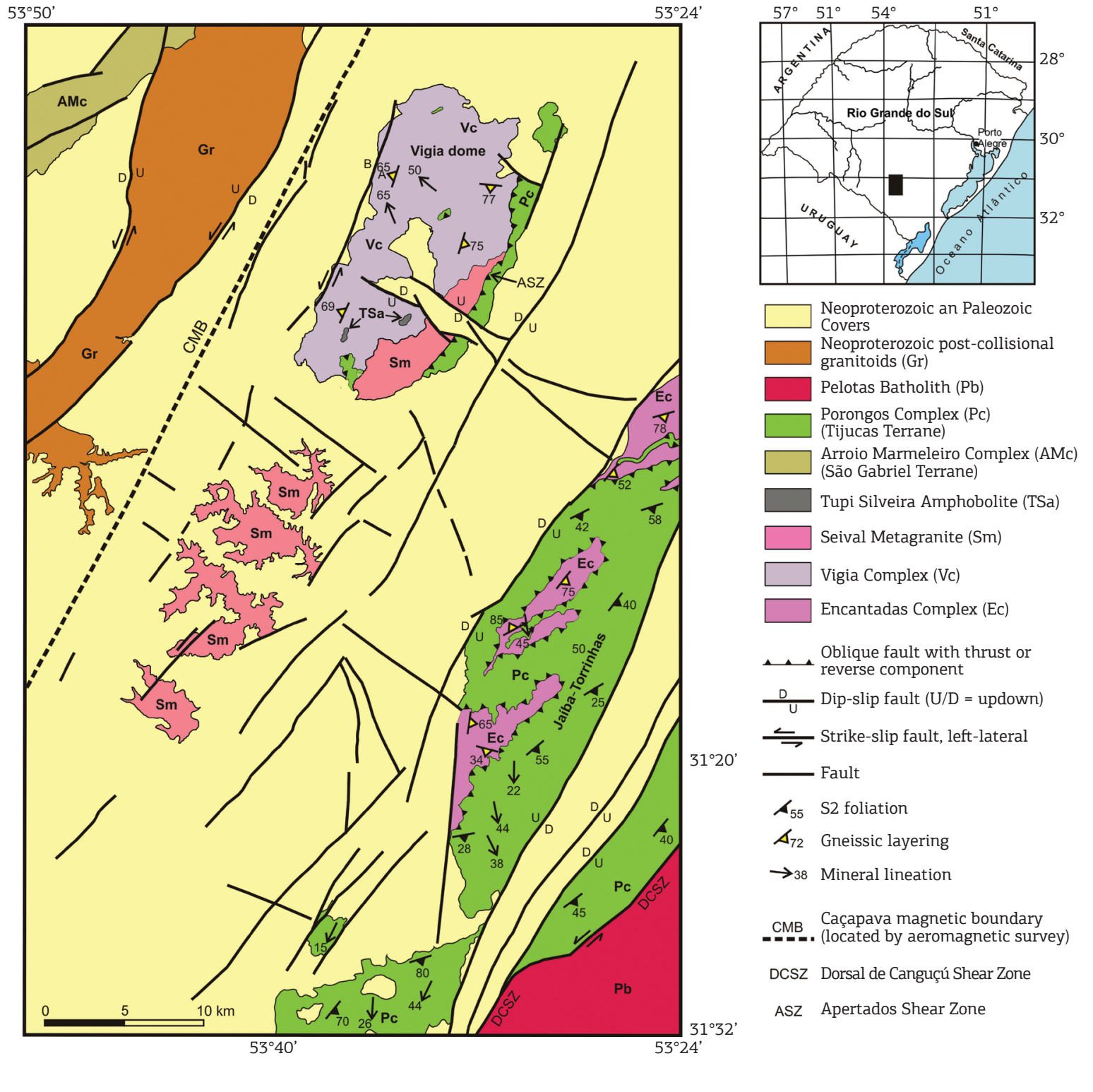

Figure 9. Geological map of Hulha Negra region, south portion of Tijucas Terrane (Camozzato et al. 2013). 
and dominant part of the complex (Santana da Boa Vista region) were derived from the erosion of Archean, Paleo- and Mesoproterozoic sources with ages between 2.9 and $2.0 \mathrm{Ga}$, and between 1.6 and $1.0 \mathrm{Ga}$, respectively (Hartmann et al. 2004, Gruber et al. 2011, Pertile et al. 2015a,b). Recent studies in the Cachoeira do Sul region, northern part of the complex, indicate that the rocks in this sector derived from Neoproterozoic sources (Gruber et al. 2011, Pertile et al. 2015a,b). LA-ICP-MS U-Pb detrital zircon ages between 850 and 700 Ma suggest that this part of the basin represents a back-arc or a foreland basin. New SHRIMP U-Pb analyses of metadacites and meta-andesites of the Santana da Boa Vista and of metarhyolites of the Piratini region gave age values of $798 \pm 6 \mathrm{Ma}, 801 \pm 5 \mathrm{Ma}, 807 \pm 7 \mathrm{Ma}$ and $803 \pm$ $4 \mathrm{Ma}$ to Cerro da Árvore metadacites (unpublished data).

Two groups of granite intrusions in the PC are recognized:

1. peraluminous granites with muscovite, garnet and tourmaline and

2. alkaline leucogranites with Fe-rich biotite and/or sodic pyroxene (Capané and Candiotinha type metagranite).

These granites are deformed and emplaced along the $S_{2}$ regional foliation. The compositional and textural characteristics were highlighted by Camozzato et al. (2012) who correlated the pearluminous granites with the intrusions of the Cordilheira Suite. U-Pb LA-ICP-MS data on zircon indicate crystallization at $589 \pm 25 \mathrm{Ma}$ for the Candiotinha Metagranite (Camozzato et al. 2013) and $601 \pm 7 \mathrm{Ma}$ for the Capané Metagranite (unpublished data). The ages obtained on the overgrowths of zircon crystals and titanite indicates metamorphism at ca. $540 \mathrm{Ma}$.

\section{Pelotas Batholith}

The Pelotas Batholith is composed of a set of Neoproterozoic (Ediacaran) granitic suites, generated during and after the climax of the Dom Feliciano orogeny. The granitic suites are elongated in the $\mathrm{N} 50-70^{\circ} \mathrm{E}$ direction, and their generation and emplacement were controlled by high angle ductile transcurrent shear zones. The batholith is a multi-intrusive $400 \times 120 \mathrm{~km}$ plutonic complex including granite, gabbro and diorite, as well as rhyolitic to basaltic dikes swarms (Fig. 10) (Philipp \& Machado 2005). The granitoids represent an early generation of high-K calc-alkaline suites with metaluminous to peraluminous affinity, followed by alkaline magmatism and, finally, less voluminous peralkaline intrusions (Philipp \& Machado 2005, Oliveira et al. 2015). Shear zones in the batholith are defined by mylonitic belts with sub-vertical foliation, accompanied by sub-horizontal stretching lineation, and were active during the development of the batholith, controlling the intrusion of the granitic suites (Fig. 10) (Fernandes et al. 1992, Koester et al. 2001b, Philipp et al. 2003). Syn-collisional episodes of compressional ductile movements were followed by an extensional post-collisional period.

The emplacement of the different intrusions took place between 650 and $550 \mathrm{Ma}$, but only a small proportion of the granite plutons have been precisely dated. The available Sr and $\mathrm{Nd}$ isotopic data suggest reworking of Paleoproterozoic continental crust (Philipp et al. 2003, 2007). The oldest unit of the batholith is the Quiteria Granite, followed by the Cordilheira Suite, Pinheiro Machado Complex, and the Viamão, Erval, Piquiri, Encruzilhada do Sul, Dom Feliciano and the Itapuã suites (Koester et al. 2001a,b, Frantz et al. 2003, Philipp et al. 2002, 2003, 2013). Despite the fact that diorites are commonly associated with the granitoids, $\mathrm{Sr}$ and $\mathrm{Nd}$ isotope data indicate a common trend of high ${ }^{87} \mathrm{Sr} /{ }^{86} \mathrm{Sr}$ initial ratios and negative $\varepsilon_{\mathrm{Nd}}$ values. The $\mathrm{Sm}-\mathrm{Nd}\left(\mathrm{T}_{\mathrm{DM}}\right)$ model ages are in the interval between 1.100 and $2.100 \mathrm{Ma}$, supporting, therefore, origin of the granitic melts by anatexis of older crustal rocks (Koester et al. 2001b, Philipp et al. 2003, 2013, 2016a).

\section{Granitic Suites}

The Quiteria Metagranite is the oldest granite in the batholith, with a U-Pb SHRIMP zircon age of $658 \pm 4 \mathrm{Ma}$ (Frantz et al. 2003). In the Quitéria region, the peraluminous granites of the Cordilheira Suite have U-Pb SHRIMP zircon ages between ca. 634 and $625 \pm 6 \mathrm{Ma}$ (Cordilheira and Francisquinho granites) and $605 \pm 8 \mathrm{Ma}$ (Figueiras granite) (Frantz et al. 2003). New LA-ICP-MS U-Pb zircon ages of peraluminous leucogranite in migmatitic pelitic gneiss of the Varzea do Capivarita Complex indicate crystallization at $620 \pm 6 \mathrm{Ma}$, whereas metamorphic zircon grains of the migmatitic gneisses have the age of $619 \pm$ $5 \mathrm{Ma}$. This indicates that the granitic magmatism of the Quitéria region represents the early stages of formation of the Pelotas Batholith (Philipp et al. 2013, 2016a).

The collisional peak was controlled by compression and new shear episodes along the Dorsal de Canguçu Shear Zone, associated with the generation of granitic to basic magmas, suggesting important anatexis. This event culminated in the generation of the granites of the Pinheiro Machado Complex and Viamão Suite. These suites present $\mathrm{U}-\mathrm{Pb}$ and $\mathrm{Pb}-\mathrm{Pb}$ TIMS zircon ages between 630 and $620 \mathrm{Ma}$ (Babinski et al. 1997 , Philipp et al. 2002, 2003, Silva et al. 1997). The geochronological data available for the Viamão Suite granites indicate U-Pb TIMS zircon ages of $595 \pm 1 \mathrm{Ma}$ for the Arroio Moinho Granite (Babinski et al. 1997), $630 \pm 6 \mathrm{Ma}$ for the Viamão Granite, and a LA-ICP-MS age of $627 \pm 16 \mathrm{Ma}$ for the Barão do Triunfo Granite (Philipp et al. 2016c).

Late to post-collisional reactivation of the shear zones between ca. 610 and $550 \mathrm{Ma}$ resulted in the emplacement of the alkaline and peralkaline Piquiri and Encruzilhada do Sul suites, and high-K calc-alkaline to alkaline granites of the Dom Feliciano suite (Vasquez, 1997, Philipp et al. 2003). Zircon from 

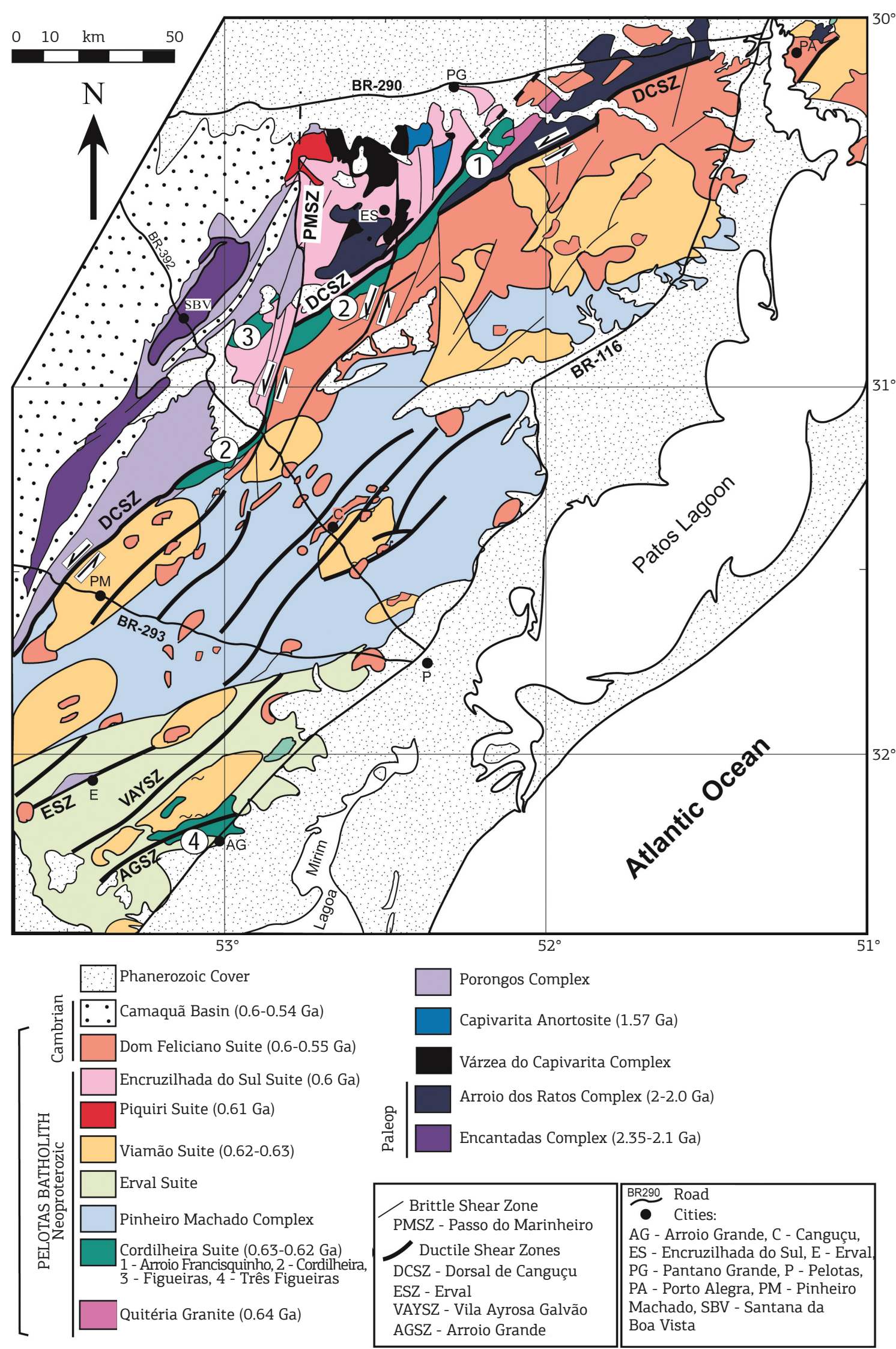

Figure 10. Geotectonic simplified map of the Pelotas Batholith (modified from Philipp et al. 2016a). 
syenites of the Piquiri Suite were dated by $\mathrm{Pb}-\mathrm{Pb}$ evaporation TIMS method, with ages of $611 \pm 3 \mathrm{Ma}$ for the Piquiri Syenite and $612 \pm 3 \mathrm{Ma}$ for the Arroio Silva Syenite (Philipp et al. 2002). Granites of the Encruzilhada do Sul Suite have the U-Pb TIMS zircon age of $595 \pm 4 \mathrm{Ma}$ (Babinski et al. 1997) and the Rb-Sr isochron age of $587 \pm 7 \mathrm{Ma}$ (Vasquez 1997). A new U-Pb LA-ICP-MS zircon age obtained by Philipp et al. (2016c) showed a value of $595 \pm 8 \mathrm{Ma}$ for the porphyritic facies of the Encruzilhada do Sul Granite.

The northern portion of the Pelotas Batholith is dominated by the voluminous post-collisional leucogranites of the Dom Feliciano Suite, emplaced at the end of the Neoproterozoic. The Ponta Grossa Granite has the U-Pb TIMS zircon age of $600 \pm 9 \mathrm{Ma}$ (Philipp et al. 2016c). A pegmatoid leucogranite cutting the Porto Alegre Gneiss crystallized at $585 \pm 6 \mathrm{Ma}$ with inheritance at $739 \pm 45 \mathrm{Ma}$. According to Oliveira et al. (2001), the Itapuã Suite includes granitoids and dike swarms of alkaline affinity that were previously included in the Dom Feliciano Suite. The suite comprises granite, syenogranite, quartz-syenite and subordinate syenite, as well as a dyke swarms of comenditic rhyolite to basalt with alkaline to peralkaline affinity (Oliveira et al. 2015). A U-Pb SHRIMP zircon age of $600 \pm 3 \mathrm{Ma}$ was reported for the Santana Granite (Koester et al. 2001a). New U-Pb LA-ICP-MS zircon data obtained indicated ages around $550 \mathrm{Ma}$ for the felsic dikes (Oliveira et al. 2015).

\section{Basement inliers and xenoliths}

During ascent and emplacement, the granitic suites captured xenoliths of the country rocks with dimensions of up to several kilometers across. Petrographic, geochemical and structural data for these xenoliths show that they are comparable to the adjacent metamorphic units of the Nico Perez Microplate. Basement inliers are represented by low to high grade metamorphic rocks, which occur in large areas in the northern portion of the batholith and as xenoliths of centimetric to decametric dimensions in the central and southern areas. The main exposures are within granites of the Encruzilhada do Sul Suite, and are xenoliths of paragneisses of the Várzea do Capivarita Complex (VCC) and orthogneisses of the Arroio dos Ratos Complex (ARC) (Fernandes et al. 1992, Philipp et al. 2016a). In the same region, in the northern part of the Pelotas Batholith, is the Capivarita Anorthosite (CA) (Chemale et al. 2011).

Large exposures of the VCC and ARC occur as "roof pendants" in granitoids of the Encruzilhada do Sul Suite and, to a lesser extent, of the Cordilheira Suite. The ARC is composed of tonalite to granodiorite gneisses cut by granites, and present tectonic contacts with the VCC paragneiss (Martil et al. 2011, Gregory et al. 2015). Rocks of both complexes were metamorphosed under medium to high grade metamorphic conditions (Lima et al. 1998, Gross et al. 2006, Philipp et al. 2013). In this area, the Capivarita Anorthosite and other Paleoproterozoic basement rocks record the collisional metamorphism under upper amphibolite to granulite facies conditions (Fernandes et al. 1992, Chemale Jr. et al. 2011, Philipp et al. 2016a). The magmatic ages of orthogneisses of the ARC are ca. 2.2 - 2.0 Ga (Leite et al. 2000, Silva et al. 2005, Gregory et al. 2015) with juvenile signatures and metamorphism at $631 \pm 13 \mathrm{Ma}$ (Silva et al. 2005).

Several other smaller gneiss bodies were described highlighting the widespread occurrence of high grade ortho- and paragneiss, and also the presence of large xenoliths of schist, quartzite and marble of the Porongos Complex in the Herval and Pedro Osório regions (Philipp et al. 2003).

The Porto Alegre gneisses have been correlated with the ARC rocks (Philipp et al. 2004). Recently, however, Koester et al. (2016) presented a Neoproterozoic U-Pb SHRIMP zircon age of $789 \pm 13 \mathrm{Ma}$ for the Chácara das Pedras orthogneiss, indicating probably a new arc generation. The xenoliths of tonalitic gneiss inside of the gneiss present a U-Pb LA-ICP-MS zircon age of $1.993 \pm 25 \mathrm{Ma}$, probably related to inheritance of ARC gneisses (Philipp et al. 2016c).

Based on the pseudosection investigation and in the paragenesis garnet-cordierite-sillimanite-biotite, the metamorphism of the VCC occurred at $720-820^{\circ} \mathrm{C}$ and pressure of 8 to 9 $\mathrm{kbar}$, characterizing it as of intermediate pressure and high temperature series (Philipp et al. 2013). Metamorphic zircon grains of a garnet-sillimanite-biotite gneiss of the VCC and of an associated peraluminous leucogranite were dated at $620 \pm$ $5 \mathrm{Ma}$ (main metamorphism) and at $612 \pm 6 \mathrm{Ma}$ for the crystallization of the leucogranite (Philipp et al. 2016a).

$\mathrm{U}-\mathrm{Pb}$ dating of magmatic and metamorphic zircon grains of the Capivarita Anorthosite yielded the age of $1573 \pm 21 \mathrm{Ma}$ and of $606 \pm 6 \mathrm{Ma}$, respectively, whereas titanite grains have the igneous crystallization age of $1530 \pm 33 \mathrm{Ma}$ and metamorphic ages of $651 \pm 9 \mathrm{Ma}$ and $601 \pm 5 \mathrm{Ma}$ (Chemale Jr. et al. 2011). The older metamorphic age is interpreted as the age of collisional metamorphism and the younger ages are related to the contact metamorphism produced by the Encruzilhada do Sul Granite. The Lu-Hf model ages of the CA showed two clusters: from 1.81 to $2.03 \mathrm{Ga}\left(\varepsilon_{\mathrm{Hf}}\right.$ from +2.2 to +6.4$)$ and from 2.55 to $2.62 \mathrm{Ga}\left(\varepsilon_{\mathrm{Hf}}\right.$ from -4.59 to -5.64$)$. This magmatism may represent an important episode of continental accretion in an extensional setting during fragmentation of a supercontinent in the Early Mesoproterozoic.

\section{The Seival volcano-sedimentary- plutonic Association}

The plutonic-volcano-sedimentary Seival Association represents the late to post-orogenic stages of the Dom Feliciano Event (Paim et al. 2000, Chemale Jr. 2000).

The main unit of this association is the Camaquã Basin, comprising four depositional successions associated with 
NE-SW shear zones (Fig. 3). In the last three sequences, the shear zones and extensional faults probably reached the mantle and lower crust levels and generated the volcanic rocks of the Hilário (Bom Jardim Group), Acampamento Velho (Santa Bárbara Group) and Rodeio formations (Guaritas Group). Large shoshonite to high-K calc-alkaline magmatism defined by elongated volcanic bodies parallel to the main transcurrent fault systems are suggestive of the role of these structures in the depositional control and also in the origin of magmatism.

Two main granitoid suites were generated in this period:

1. Shoshonitic to high-K calc-alkaline and

2. alkaline granites.

The emplacement of the shoshonitic granitoids such as the Lavras do Sul is associated with the deposition of the Bom Jardim Group, whereas the sedimentary and volcanic rocks of the Santa Barbara Group are contemporaneous with the emplacement of the Acampamento Velho Formation rhyolites and high-K calc-alkaline granitoids such as the Caçapava do Sul Granite and of alkaline granitoids such as the Jaguari, Ramada, Cerro da Cria and São Sepé granites.

\section{Camaquã Basin}

Sedimentary rocks of the Camaquã Basin have ages between $600 \mathrm{Ma}$ and $540 \mathrm{Ma}$ (Paim et al. 2000, Chemale Jr. 2000, Oliveira et al. 2014). The basin is formed by different sedimentary and volcano-sedimentary units, with associated plutonic rocks, and separated from each other by angular or erosional unconformities of regional character. The basin was filled and deformed during the late stages of the Brasiliano orogeny. The deposition is believed to have evolved from marine environments (Maricá Group), through transitional between marine and lacustrine conditions (Bom Jardim and Santa Barbara Groups) to fluvial and lacustrine environments (Guaritas Group) (Figs. 4, 5, 7, 8 and 9). The first two cycles are controlled by NE-SW shear zones associated with transcurrent compressive tectonics under ruptile-ductile conditions. The last three depositional episodes started with the eruption of volcanic rocks with tholeiitic, high-K calc-alkaline to shoshonitic characteristics (Hilário Formation, Bom Jardim Group), changing later to bimodal tholeiitic to sodic alkaline nature (Acampamento Velho Formation, Santa Barbara Group) and finishing with alkaline basaltic volcanics (Rodeio Velho Formation, Guaritas Group) (Wildner et al. 2002, Sommer et al. 2005, Janikian et al. 2012).

The Maricá Group is interpreted to be formed as retro-arc foreland basin due collision of the Rio de la Plata and Encantadas microcontinent (Borba et al. 2006, 2008). The overlying Bom Jardim Group is resulted from transpressive tectonics and associated volcanism (Paim et al. 2000). The upper section of the Camaquã Basin is a transtensional rift basin developed when amalgamation of the shield was already completed (Oliveira et al. 2015). The high-K calc-alkaline plutons have SHRIMP and LA-ICP-MS $\mathrm{U}-\mathrm{Pb}$ ages between 598 and $570 \mathrm{Ma}$, whereas the alkaline plutons crystallized between 570 - 550 Ma.

\section{EVOLUTION OF THE DOM FELICIANO BELT}

The early evolution of the DFB involved the deformation of the sedimentary rocks at the western passive margin of the Nico Perez Microplate and of the Paleoproterozoic units of the sialic basement (Fig. 11). The metamorphic evolution of the Dom Deliciano belt took place during two main collisional events. The first collision occurred between the arc systems (Passinho and São Gabriel) and the Nico Perez Microplate at ca. $720-710 \mathrm{Ma}$ along the western portion of the belt, associated with the closure of the Charrua Ocean. Subduction related low- to medium-K calc-alkaline plutonic and volcano-sedimentary associations are represented in the São Gabriel Terrane by the Passinho and São Gabriel arcs (Saalmann et al. 2005, 2010). The second and most important collisional event is believed to have been an oblique collision between the RLPC/Nico Perez Microplate (or Encantadas Microplate, Chemale Jr. 2000) and the Kalahari Craton between 650 and $620 \mathrm{Ma}$ (Chemale Jr. et al. 2011, Camozzato et al. 2012, 2013, Gregory et al. 2015, Philipp et al. 2016a). This event also caused the strong deformation of the arc related rocks, passive margin sedimentary rocks and of units of the sialic basement. The process led to the anatexis of the metamorphic units (Philipp et al. 2013, 2016a).

\section{The Basement}

The margins of the Nico Perez Microplate in RS is extremely deformed and affected by two main events $(800-760 \mathrm{Ma}$ and $650-550 \mathrm{Ma}$ ) and by intense granitic magmatism with subordinate volcanic rocks. Isotopic data suggest that fragments of the Nico Perez Microplate are widespread in many areas of the DFB. These gneisses are Paleoproterozoic, and their parental granitic rocks formed during three orogenic episodes: Siderian (Santa Maria Chico Granulitic Complex, 2.37 to $2.35 \mathrm{Ga}$ ), Rhyacian (Encantadas, Vigia and Arroio dos Ratos complexes, 2.2. to $2.1 \mathrm{Ga}$ ), and less abundant Statherian rocks (Seival Metagranite, 1.78 to $1.75 \mathrm{Ga}$ ) (Camozzato et al. 2012, 2013, Philipp et al. 2013, 2016c). These units have been intruded by Calymmian ( 1.57 to $1.55 \mathrm{Ga}$ ) anorogenic basic rocks, represented in the Tijucas Terrane by the Tupi Silveira Amphibolite and in the Pelotas Batholith by the Capivarita Anorthosite (Camozzato et al. 2012, 2013, Chemale Jr. et al. 2011). 


\section{Closure of the Charrua Ocean}

The construction of the Neoproterozoic DFB starts with the closure of the Charrua Ocean during the Passinho and São Gabriel orogenies and later with the collision between the arc systems and the western margin of the Nico Perez Microplate. The final stages of evolution of the Brasiliano orogenic cycle are marked by the closure of the Adamastor Ocean during the Dom Feliciano orogeny. This orogenesis is characterized by the emplacement of voluminous syn-collisional high-K calc-alkaline granites of metaluminous to peraluminous character, associated with high-grade metamorphism coeval with the collision between the Rio de La Plata and Kalahari cratons. The collapse of the Dom Feliciano Belt is defined by important late- to post-orogenic granitic magmatism of high-K calc-alkaline to alkaline affinity. This is accompanied by the deposition of the four sedimentary successions of the Camaquã Basin, the last three associated with intense volcanic activity.
During the last two decades, arc-related Neoproterozoic plutonic complexes and volcano-sedimentary sequences have been recognized in Goiás and Rio Grande do Sul. These important subduction-related juvenile crustal accretions took place during the Tonian (Leite et al. 1998, Saalmann et al. 2010, Philipp et al. 2014). These associations suggest that the duration of the Brasiliano orogeny and ocean plate subduction was substantially longer than what has been suggested in previous models. They demonstrate the existence of small ocean basins separating continental microplates, which were later amalgamated.

The new geochronological and isotopic data indicate that subduction between 900 and $700 \mathrm{Ma}$ marked the initial stages of the Neoproterozoic orogenic events in southern Brazil (e.g. Hartmann et al. 2011). The rock units which represent this period of oceanic lithosphere consumption are exposed only in the São Gabriel Terrane. Opening of the oceanic basin between the RLPC and Nico Perez Microplate started at least 0.95-0.9 Ga ago (Saalmann et al. 2005, 2006, Arena \& Hartmann, 2015) (Fig. 11). Subduction of oceanic

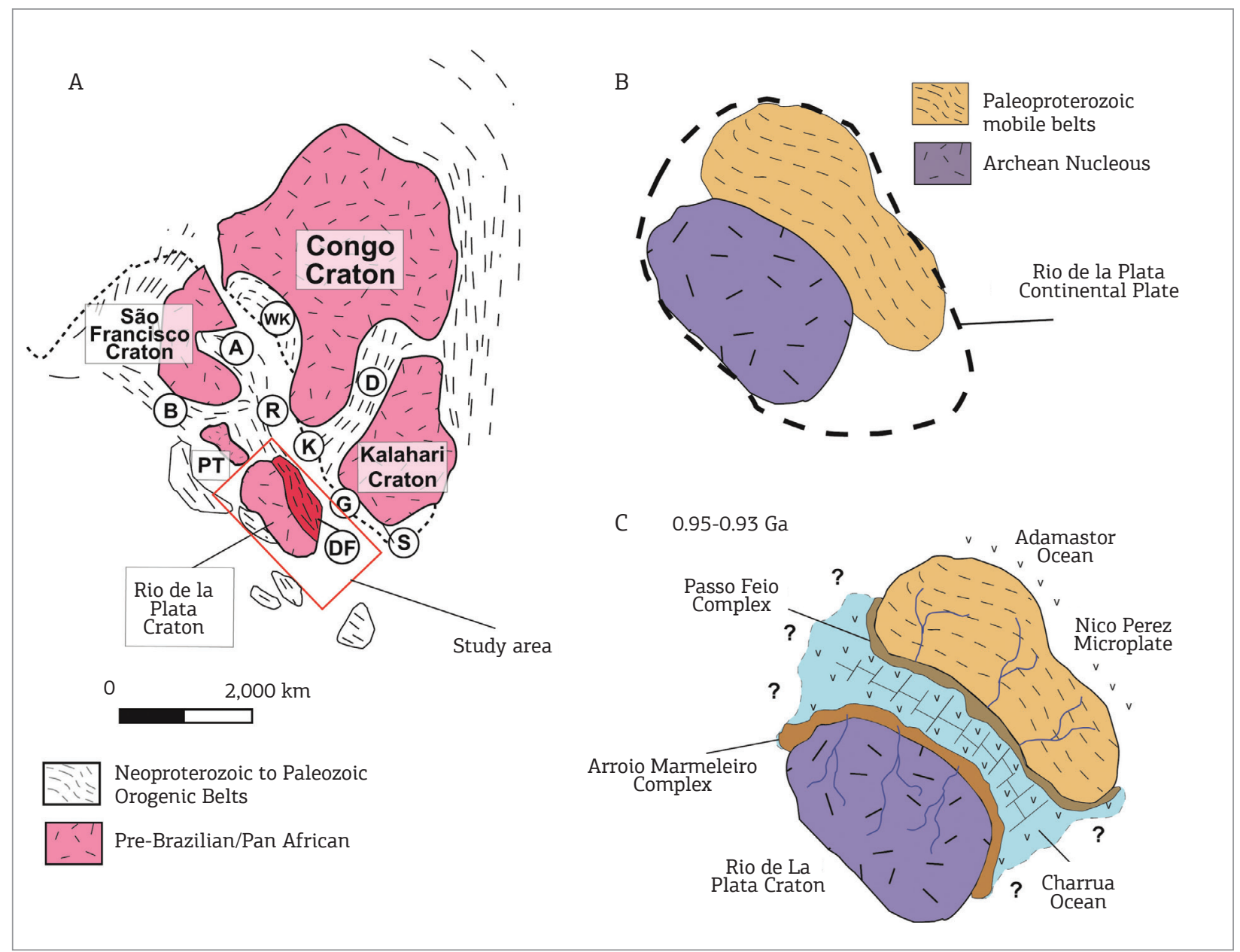

Figure 11. (A) Southern portion of Gondwana showing the main cratonic areas and the location of the Dom Feliciano belt and related belts of Africa. (B) Detail of the compositon of the Rio de La Plata continental plate, highlighting the archean nucleus. (C) Opening of the Charrua Ocean between the Rio de La Plata Craton (old nucleus) and the Nico Perez Microplate (paleoproterozoic mobile belt). 
lithosphere started at about 900 to $860 \mathrm{Ma}$ leading to the development of the Passinho Arc, an intraoceanic island arc above an east-dipping subduction zone (e.g.:Philipp et al. 2014, Lusa et al. 2016). Eastward subduction beneath the Nico Perez Microplate resulted in the establishment of the São Gabriel Arc, with active continental margin magmatism with main activity between 780 and $700 \mathrm{Ma}$ (Saalmann et al. 2010, Hartmann et al. 2011 and references therein).

Dextral oblique collision of the arc systems and accretion to the west passive margin of the Nico Perez Microplate occurred between ca. 710 and $700 \mathrm{Ma}$ (Remus et al. 1999). The colapse of the orogen is defined by the formation of a late-orogenic basin represented by the metasediments of the Pontas do Salso Complex, with a maximum age of ca. $680 \mathrm{Ma}$ (Vedana et al. 2016).

\section{Closure of the Adamastor Ocean}

The Porongos Complex (PC) formed along the eastern passive margin of the Nico Perez Microplate. The geocronological data suggest Paleoproterozoic sources within the Nico Perez and Archean sources from Rio de La Plata, Congo and Kalahari cratons for sediments of this part of the complex. Mesoproterozoic zircon grains may have been derived from the Andean basement situated in the central part of Argentina or, alternatively, from southern Africa (Hartmann et al. 2004, Gruber et al. 2011, Pertile et al. $2015 a, b)$. The field data associated with the provenance data suggest that the Porongos basin originated as an east passive margin basin of the Nico Perez Microplate. On the other hand, the geochemical and U-Pb ages of metavolcanic rocks of the PC suggest that they formed in a continental magmatic arc. These data are supported by the age of Piratini Gneisses (Silva et al. 1997) and by the new data of Koester et al. (2016). The Lu-Hf data presented by Pertille et al. (2015b) indicate that the Porongos metavolcanic rocks derived from an old crustal source aged between 2.4 and $2.2 \mathrm{Ga}$, and could not be correlated with the São Gabriel Arc metavolcanics. The metavolcanic rocks of the Bossoroca Complex display positive $\varepsilon_{\mathrm{Hf}}(+8$ to +12$)$ and source age of 0.9 to $1.0 \mathrm{Ga}$ (unpublished data).

The volcano-sedimentary rocks of the Porongos Complex exposed in the Cachoeira do Sul area display features which are different from those of the Santana da Boa Vista region, since they show Neoproterozoic provenance and geochemical characteristics which are indicative of magmatic arc sources (Saalmann et al. 2006, Pertile et al. 2015a,b). The data might suggest the existence of a younger foreland basin.

Two granite groups have been identified within the Porongos Complex:

1. calc-alkaline muscovite- and tourmaline-bearing peraluminous granites, and

2. alkaline and peralkaline intrusions with aegirine and biotite.
Granites of the first group are coeval with collisional metamorphism, and the younger are late-orogenic and associated with late-stage movements of the high-angle shear zones in the northern (Cachoeira do Sul) and southern (Candiota) areas of the Tijucas Terrane (Camozzato et al. 2012, 2013).

The deformation prograded to the east, being recorded in left-lateral ductile shear zones along the Dorsal de Canguçu Shear Zone which was active between 650 and $620 \mathrm{Ma}$ (e.g.: Fernandes et al. 1992; Philipp et al. 2003, 2013, 2016a). The sialic basement of this region, represented by orthogneisses of the ARC and paragneisses of the VCC, have been strongly deformed and metamorphosed under medium- to high-grade and intermediate pressure conditions. As a result of the oblique collision, the Dorsal de Canguçu Shear Zone formed, which caused partial melting in the mantle or lower crustal depths. While this shear zone was active, large volumes of granitic magmas formed, including, for example, the 650 Ma old Quitéria Granite (Koester et al. 2001b), as well as a smaller volume of mafic magmas.

The second and most important collisional event was the oblique collision between the RLPC/Nico Perez Microplate and Kalahari Craton between 650 and $620 \mathrm{Ma}$ (Chemale Jr. et al. 2011, Gregory et al. 2015, Philipp et al. 2016a). The displacement of the basement terrains along the NE-SW transcurrent shear zones was also responsible for generating space for the emplacement of the granitic suites. The anatexis associated to the late stage of collisional process generated large volumes of high-K calc-alkaline granitic magmas and resulted in the formation of the Pelotas Batholith and associated mafic and felsic magmatism of the Camaquá Basin (Philipp et al. 2013, 2016a). This magmatism started with the development of the Dorsal do Canguçu Shear Zone and emplacement of the Quitéria granite. This event took place during or right after the peak of collisional metamorphism generating anatexis of the pelitic gneisses of the VCC and of the orthogneisses of the ARC. Pseudosection studies suggest temperatures between 740 and $820^{\circ} \mathrm{C}$ and pressures of 9 to $10 \mathrm{kbar}$ (Philipp et al. 2013).

The Cordilheira Suite formed during this event at ca. 650 and $620 \mathrm{Ma}$ (Philipp et al., 2013, 2016a). The collision generated large volumes of high-K calc-alkaline granites and resulted in the formation of the Pelotas Batholith. The Cordilheira and Arroio Francisquinho granites are the main bodies of the Cordilheira Suite and are emplaced along the the Dorsal de Canguçu Shear Zone. The increase in thermal gradient and ascent of the asthenosphere at the base of the orogen may have contributed to extensive anatexis and generation of peraluminous granitoids.

Following continental collision, between 600 and $570 \mathrm{Ma}$, the development and emplacement of the Pelotas Batholith took place in the lower crust associated with ductile transcurrent shear zones. Left-lateral shear also characterized 630 - $550 \mathrm{Ma}$ deformation in the Pelotas Batholith further to the east. Late-orogenic plutonic, volcanic and sedimentary 
units of the Seival Association formed under transtensional to extensional environments between 590 and $500 \mathrm{Ma}$, resulting in the orogenetic collapse of the DFB.

\section{CONCLUSIONS}

The recent isotope data indicate that the the evolution of the DFB took place between 0.9 and $0.54 \mathrm{Ga}$. Three orogenic events known as the Passinho $(0.9$ - $0.86 \mathrm{Ga})$, São Gabriel (0.77 $0.68 \mathrm{Ga})$ and Dom Feliciano $(0.65-0.54 \mathrm{Ga})$ are recognized.

The evolution of the São Gabriel Terrane is preserved in igneous zircon grains, indicating ages of $0.93 \mathrm{Ga}$ to 0.9 for the opening of the Charrua Ocean and 0.9 to $0.7 \mathrm{Ga}$ for the closure and generation of the intraoceanic Passinho Arc (0.9 - 0.86 $\mathrm{Ga})$ and the São Gabriel Arc $(0.77-0.68 \mathrm{Ga})$. The collision of the arc systems against the Nico Perez Microplate occurred around $0.71-0.7 \mathrm{Ga}$, and the collapse of the SGT is marked by the deposition of the Pontas do Salso Complex at $680 \mathrm{Ma}$.

The Tijucas Terrane is composed of the Paleoproterozoic orthogneiss domes of Santana da Boa and Vigia (Siderian and Rhyacian) and of Neoproterozoic metavolcano-sedimentary rocks (Cryogenian). The Taquarembó Terrane present the largest area of Paleoproterozoic orthogneisses (Siderian), intruded by granites and covered by Neoproterozoic sedimentary and volcanic rocks.

All units of the Dom Feliciano Belt were mapped on a regional scale and the inclusion of this database with the current set of geochronological and isotopic data has provided significant advances in the understanding of its units and the correlation of the processes with other orogenic belts of Brazil and Africa.

\section{ACKNOWLEDGMENTS}

We would like to aknowledge the Brazilian National Council for Scientific and Technological Development (CNPq) for the research grants, the Geoscience Institute of Universidade Federal do Rio Grande do Sul (UFRGS) for field work support and laboratories, and the Geochronology Research Center of Universidade de São Paulo (USP), for the access to LA-ICP-MS laboratories. We are grateful to Eduardo Camozzato, Jorge Laux, Enrique Iglesias, Romulo Machado, Miguel A.S. Basei and reviewers for the helpful comments and suggestions, and to Marly Babinski for comments and editorial handling of the manuscript.

\section{REFERENCES}

Arena K. R. \& Hartmann L. A. 2015. Zircon U-Pb SHRIMP Dating of albitites from the Tonian Cerro Mantiqueiras and Ibaré ophiolites, São Gabriel Terrane, Southern Brazilian Shield. In IX Simpósio SulBrasileira de Geologia, Florianópolis, Boletim de Resumos, p. 145.

Babinski M., Chemale Jr. F., Hartmann L.A., Van Schmus W.R., Silva L.C. 1996. Juvenile accretion at 750-700 Ma in southern Brazil. Geology, 24:439-442

Babinski M., Chemale Jr. F., Van Schmus W.R., Hartmann L.A., Silva L.C. 1997. U-Pb and Sm-Nd Geochronology of the Neoproterozoic Granitic-Gneissic Dom Feliciano Belt, southern Brazil. Journal of South American Earth Sciences, 3-4:263-274.

Basei M.A.S., Frimmel H.E., Nutman A.P., Preciozzi F. 2008. West Gondwana amalgamation based on detrital zircon ages from Neoproterozoic Ribeira and Dom Feliciano belts of SouthAmerica and comparison with coeval sequences from SW Africa. In: Pankhurst R.J., Trouw R.A.J., Brito Neves B.B., de Wit M.J. (eds). West Gondwana, Pre-Cenozoic correlations across the South Atlantic region. Geological Society, London, Special Publication, 294:239-256.

Basei M.A.S., Campos Neto M.C., Castro N.A., Nutman A.P., Wemmer M.T., Yamamoto M.T., Hueck M., Osako L., Siga Jr. O., Passarelli C.R. 2011. Tectonic evolution of the Brusque Group, Dom Feliciano belt, Santa Catarina, Journal of South American Earth Sciences, 32:324-350.

Bitencourt M.F. \& Nardi L.V.S. 2000. Tectonic setting and sources of magmatism related to the Southern Brazilian Shear Belt. Revista Brasileira de Geociências, 30:186-189.

Borba A.W., Mizusaki A.M.P., Silva D.R.A., Noronha F.L., Casagrande J. 2006. Provenance of the Neoproterozoic Maricá Formation
(Sul-rio-grandense Shield, Southern Brazil): petrographic and SmNd isotopic constrains. Gondwana Research, 9:464-474.

Borba A.W., Mizusaki A.M.P., Santos, J.O.S., Mc Naughton, N.J., Onoe, A.T., Hartmann, L.A. 2008. U-Pb zircon and ${ }^{40} \mathrm{Ar}-{ }^{39} \mathrm{Ar} \mathrm{K}$-feldspar dating of syn-sedimentary volcanism of the Neoproterozoic Maricá Formation: constraining the age of foreland basin inception and inversion in the Camaquã Basin of southern Brazil. Basin Research, 20:359-375

Camozzato E., Lopes R.C., Philipp R.P. 2012. Mapa Geológico da Folha Hulha Negra (SH.22.Y-C-1), escala 1:100.000. Rio de Janeiro, Programa Levantamentos Geológicos, CPRM. v.1, 128 p.

Camozzato E., Philipp R.P., Chemale Jr. F. 2013. Evolução Tectônica e Geocronologia U-Pb em zircão da terminação sul do Terreno Tijucas (RS, Brasil). In: VII Congreso Uruguayo de Geología, Montevideo, Resúmenes Extendidos, p. 7.

Chemale Jr. F. 2000. Evolução Geológica do Escudo Sul-RioGrandense. In: Holz M., De Ros L.F. (eds.) Geologia do Rio Grande do Sul. Editora UFRGS, Porto Alegre, p. 13-52.

Chemale Jr. F. Philipp R.P., Dussin I., Formoso M.L.L., Kawashita K., Berttotti A.L. 2011. Lu-Hf and U-Pb age determination of the Capivarita Anorthosite, Dom Feliciano belt, Brazil, Precambriam Research, 186:117-126.

Chemale Jr. F., Mallmann G., Bitencourt M.F., Kawashita K. 2012. Time constraints on magmatism along the Major Gercino Shear Zone, southern Brazil: implications for West Gondwana reconstruction. Gondwana Research, 22:184-199.

Cordani U.G., Brito Neves B.B., D’Agrella Flo. M. 2003. From Rodínia to Gondwana: A review of the Available Evidence from South America. Gondwana Research, 6:275-283. 
Fernandes, L.A., Tommasi, A., Porcher, C.C. 1992. Deformation patterns in the southern Brazilian branch of the Dom Feliciano Belt, a reappraisal. Journal of South American Earth Sciences, 5(1):77-96.

Garavaglia, L., Bitencourt, M.F., Nardi, L.V.S. 2002. Cumulatic diorites related to Post-collisional, Brasiliano/Pan-African mafic magmatism in the Vila Nova Belt, Southern Brazil, Gondwana Research, 5(2): 519-534.

Gregory T.R., Bitencourt M.A.F.S., Nardi L.V.S., Florisbal L.M., Chemale Jr. F. 2015. Geochronological data from TTG-type rock associations of the Arroio dos Ratos Complex and implications for crustal evolution of southernmost Brazil in Paleoproterozoic times. Journal of South American Earth Sciences, 57:49-60.

Gross A.O.M.S, Porcher C.C., Fernandes L.A.D., Koester E. 2006. Neoproterozoic low-pressure/high-temperature colisional metamorphic evolution in the Varzea do Capivarita Metamorphic Suite, SE Brazil: Thermobarometric and Sm/Nd evidence. Precambrian Research, 147:41-64

Gruber L., Porcher C.C., Lens C., Fernandes L.A.D. 2011. Proveniência dos metassedimentos das seqüências Arroio Areião, Cerro Cambará e Quartzo Milonitos no Complexo Metamórfico Porongos, Santana da Boa Vista, RS. Pesquisas em Geociências, 38(3):205-223.

Hartmann L.A., Leite J.A.D., Mc Naughton N.J., Santos J.O.S. 1999 Deepest exposed crust of Brazil-SHRIMP establishes three events. Geology, 27:947-950

Hartmann L.A., Leite J.A.D., Silva L.C., Remus M.V.D., McNaughton N.J., Groves D.I., Fletcher I.R., Santos J.O.S., Vasconcellos M.A.Z. 2000. Advances in SHRIMP geochronology and their impact on understanding the tectonic and metallogenic evolution of southern Brazil. Australian Journal of Earth Sciences, 47:829-843.

Hartmann L.A., Santos J.O.S., Cingolani C., McNaughton N. 2002. Two Paleoproterozoic orogenies in the evolution of the Tandilia Belt, Buenos Aires, as evidenced by Zircon U-Pb SHRIMP geochronology. Internation Geology Review, 44:528-543.

Hartmann L.A., Santos J.O.S., Leite J.A.D., Porcher C.C., McNaughton I., Neal J., 2003. Metamorphic evolution and U-Pb zircon SHRIMP geochronology of the Belizário ultramafic amphibolite, Encantadas Complex, southernmost Brazil. Anais Academia Brasileira de Ciências, 75(3):393-403.

Hartmann L.A., Philipp R.P., Liu D., Wan Y., Wang Y., Santos J.O.S., Vasconcellos M.A.Z. 2004. Paleoproterozoic magmatic provenance of detrital zircons, Porongos complex quartzites, southern Brazilian shield. Internation Geology Review, 46:127-157.

Hartmann L.A., Liu D., Wang Y., Massonne H-J., Santos J. 2008. Protolith age of Santa Maria Chico granulites dated on zircons from an associated amphibolite-facies granodiorite in southernmost Brazil. Anais da Academia Brasileira de Ciências, 80:543-551.

Hartmann L.A., Philipp R.P., Santos J.O.S., McNaughton N.J. 2011. Time frame of 753-680 Ma juvenile accretion during the São Gabriel orogeny, southern Brazil. Gondwana Research, 19:84-99.

Heilbron M. \& Machado N. 2003. Timing of terrane accretion in the Neoproterozoic-Eopaleozoic Ribeira orogen (SE, Brazil). Precambrian Research, 125(1-2):87-112

Janikian L., Almeida R.P., Fragoso-Cesar A.R.S., Martins V.T.S., Dantas E.L., Tohver E., Mc Reath I., D’Agrella Filho M.S. 2012. Ages (U$\mathrm{Pb}$ SHRIMP and LA-ICP-MS) and stratigraphic evolution of the Neoproterozoic volcano-sedimentary successions from extensional Camaquã Basin, Southern Brazil. Gondwana Research, 21:466-482.

Koester E., Soliani Jr. E., Leite J.A.D., Hartmann L.A., Fernandes L.A.D., Santos J.O.S., Oliveira L.D. 2001a. SHRIMP U-Pb age for the emplacement of Santana granite and reactivation of the Porto Alegre Suture, southern Brazil. Journal of South American Earth Sciences, 14:91-99.
Koester E., Roisenberg A., Fernandes L.A.D., Soliani Jr. E., Nardi L.V.S., Kraemer G. 2001b. Petrologia dos granitóides sintectônicos à Zona de Cisalhamento Transcorrente Dorsal de Canguçu, Encruzilhada do Sul, RS. Revista Brasileira de Geociências, 31(2):131-140.

Koster E., Porcher C.C., Pimentel M.M., Fernandes L.A.D., VignolLelarge M.L., Oliveira L.D., Ramos R.C. 2016. Further evidence of 777 Ma subduction-related continental arc magmatism in Eastern Dom Feliciano Belt, southern Brazil: the Chácara das Pedras Orthogneiss. Journal of South American Earth Sciences. Available online 7 January 2016, in press.

Leite J.A.D., Hartmann L.A., McNaughton N.J., Chemale Jr. F. 1998. SHRIMP U/Pb zircon geochronology of Neoproterozoic juvenile and crustal-reworked terranes in southernmost Brazil. International Geology Review, 40:688-705

Leite J.A.D., Hartmann L.A., Fernandes L.A.D., McNaughton N.J. Soliani Jr. E., Koester E., Santos J.O.S., Vasconcellos M.A.Z. 2000. Zircon U-Pb SHRIMP dating of gneissic basement of the Dom Feliciano Belt, southernmost Brazil. Journal of South American Earth Sciences, 13:739-750.

Lena L.O.F., Pimentel M.M., Philipp R.P., Armstrong R., Sato K. 2014 The evolution of the Neoproterozoic São Gabriel juvenile terrane, southern Brazil based on high spatial resolution U-Pb ages and ${ }^{18} \mathrm{O}$ data from detrital zircons. Precambrian Research, 247:126-138.

Porcher C.A., Wildner W. 1998. Granulitos da região da Várzea do Capivarita - Bloco Encruzilhada do Sul, RS. Pesquisas em Geociências, 25(1):27-33.

Lopes C.G., Pimentel M.M., Philipp R.P., Gruber L., Armstrong R. Junges S.L. 2015. Provenance of the Passo Feio Complex, São Gabriel Terrane, Dom Feliciano Belt, southern Brazil, implications for the tectonic setting of deposition, age of the São Gabriel Arc and origin of Paleoarchean detrital zircons (3.3-3.63 Ga). Journal of South American Earth Sciences, 58:9-17.

Lusa M., Philipp R.P., Zvirtes G. 2016. The Neoproterozoic São Gabriel orogeny, Dom Feliciano Belt, southernmost Brazil: the intra-oceanic Passinho arc and the active continental margin of the São GabrielVila Nova Arc, Lavras do Sul, southernmost Brazil. Journal of South American Earth Science, submitted.

Machado N., Koppe J.C., Hartmann L.A. 1990. A Late Proterozoic U-Pb age for the Bossoroca Belt, Rio Grande do Sul, Brazil. Journal of South American Earth Sciences, 3:87-90.

Martil M.M.D., Bitencourt M.F., Nardi L.V.S. 2011. Caracterização estrutural e petrológica do magmatismo pré-colisional do Escudo Sul-rio- grandense: os ortognaisses do Complexo Metamórfico Várzea do Capivarita. Pesquisas em Geociências, 38(2):181-201.

Oliveira D.S., Sommer C.A., Philipp R.P., Lima E.F., Basei M.A.S. 2015. Post-collisional subvolcanic rhyolites associated to the Neoproterozoic Batholith Pelotas, Southern Brazil. Journal of South American Earth Sciences, 63:84-100.

Oliveira L.D., Koester E., Soliani Jr. E. 2001. Geoquímica das rochas graníticas pós-transcorrentes da região de Porto Alegre e Viamão, RS. Geochimica Brasiliensis, 15(2):65-92.

Oliveira C.H.E., Chemale Jr. F., Jelinek A.R., Bicca M.M., Phillip R.P. 2014. U-Pb and Lu-Hf Isotopes applied to the evolution of the late to post-orogenic transtensional basins of the Dom Feliciano Belt, Brazil. Precambrian Research, 246:240-255.

Oyhantçabal P., Siegesmund S., Wemmer K. 2011. The Rio de la Plata Craton, a review of units, boundaries, ages and isotopic signature. International Journal of Earth Sciences, 100:201-220.

Paim P.S.G., Chemale Jr. F., Lopes C. 2000. A Bacia do Camaquã Geologia do Rio Grande do Sul, CIGO/UFRGS, Porto Alegre, p. 231-274 
Pertille J., Hartmann L.A., Philipp R.P. 2015a. Zircon U-Pb age constraints on the Paleoproterozoic sedimentary basement of the Ediacaran Porongos Group, Sul-Riograndense Shielf, southern Brazil: Journal of South American Earth Sciences, 63:334-345.

Pertille J., Hartmann L.A., Philipp R.P., Petry T.S., Lana C.C. 2015b. Origin of the Ediacaran Porongos Group, Dom Feliciano Belt, southern Brazilian Shield, with emphasis on whole rock and detrital zircon geochemistry and U-Pb, Lu-Hf isotopes. Journal of South American Earth Sciences, 64:69-93.

Philipp R.P., Machado R., Nardi L.V.S., Lafon J.M. 2002. O magmatismo granítico Neoproterozóico do Batólito Pelotas no sul do Brasil: novos dados e revisão de geocronologia regional. Revista Brasileira de Geociências, 32(2):277-290

Philipp R.P., Machado R., Chemale Jr. F. 2003. Reavaliação e novos dados geocronológicos sobre o Batólito Pelotas: implicações petrogenéticas e idade das zonas de cisalhamento. Boletim do Instituto de Geociências da USP, São Paulo, 3:71-84.

Philipp R.P. \& Campos R.S. 2004. Geologia, Petrografia e Litogeoquímica dos Gnaisses Porto Alegre, RS, Brasil: Implicações Geotectônicas. Revista Pesquisas em Geociências, 31(2):79-94.

Philipp R.P. \& Machado R. 2005. The Neoproterozoic to Cambrian granitic magmatism of Pelotas Batholith, Southern Brazil. Journal of South American Earth Sciences, 19:461-478.

Philipp R.P., Lusa M., Nardi L.V.S. 2008. Geochemistry and petrology of dioritic, tonalitic and trondhjemitic gneisses from Encantadas Complex, Santana da Boa Vista, southernmost Brazil, a Paleoproterozoic continental-arc magmatism. Anais da Academia Brasileira de Ciências, 80:1-14.

Philipp R.P., Massone H.J., Campos R.S. 2013. Peraluminous leucogranites of Cordilheira Suite, record of Neoproterozoic collision and generation of Pelotas Batholith, Dom Feliciano Belt, southern Brazil. Journal of South American Earth Sciences, 43:8-24.

Philipp R.P., Hartmann L.A., Lusa M., Basei M.A.S., Santos J.O.S. 2014. Oldest age of magmatism in the Passinho Arc in the southwestern portion of Gondwana, Rio Grande do Sul, Brazil. In: 9 South American Symposium on Isotope Geology, Abstracts. São Paulo, p.186.

Philipp R.P., Bom F.M., Pimentel M.M., Junges S.L., Zvirtes G. 2016a. SHRIMP U-Pb age and high temperature conditions of the collisional metamorphism in the Várzea do Capivarita Complex: implications for the origin of Pelotas Batholith, Dom Feliciano Belt, southern Brazil. Journal of South American Earth Sciences, 66:196-207.

Philipp R.P., Lusa M., Chemale Jr. F., Archanjo C., Nardi L.V.S. 2016b. The Paleoproterozoic (Siderian to Rhyacian) continental-arc magmatism of the Encantadas Complex, southernmost Brazil and his significance for evolution of the Rio de la Plata Craton. Journal of South American Earth Sciences, submitted.

Philipp R.P.; Jelinek A.R.; Chemale Jr. F. 2016c. Post-collisional Neoproterozoic magmatism of the Pelotas Batholith, Dom Feliciano Belt, RS, southernmost Brazil. International Geology Review, submitted.

Rapela C.W. ,Fanning C.M., Casquet C., Pankhurst R.J., Spalletti L., Poiré D., Baldo E.G. 2011. The Rio de la Plata craton and the adjoining Pan-African/brasiliano terranes: Their origins and incorporation into south-west Gondwana. Gondwana Research, 20:673-690.

Remus M.V.D., McNaughton N.J., Hartmann L.A., Koppe J.C., Fletcher I.R., Groves D.I., Pinto V.M. 1999. Gold in the Neoproterozoic juvenile Bossoroca volcanic arc of southernmost Brazil, isotopic constraints on timing and sources. Journal of South American Earth Sciences, 12:349-366

Remus M.V.D., Hartmann L.A., McNaughton N.J., Groves D.I., Fletcher I.R. 2000. The link between hydrothermal epigenetic copper mineralization and the Caçapava Granite of Brasiliano Cycle in southern Brazil. Journal of South American Earth Sciences, 13:191-216.

Saalmann K., Hartmann L.A., Remus M.V.D. 2005. Tectonic evolution of two contrasting schist belts in southernmost Brazil, A plate tectonic model for the Brasiliano Orogeny. International Geology Review, 47:1234-1259.

Saalmann K., Remus M.V.D., Hartmann L.A. 2006. Tectonic evolution of the Neoproterozoic juvenile São Gabriel belt, southern Brazil constraints on Brasiliano orogenic evolution of the La Plata Cratonic margin. Journal of South American Earth Sciences, 21:204-227.

Saalmann K., Gerdes A., Lahaye Y., Hartmann L.A., Remus M.V.D., Laufer A. 2010. Multiple accretion at the eastern margin of the Rio de La Plata craton, the prolonged Brasiliano orogeny in southernmost Brazil. International Journal Earth Sciences, 100:355-378.

Silva Filho B.C. 1984. Geology of the poliphase deformed Precambrian Terrane of the Vila Nova Region, State of Rio Grande do Sul, Southern Brazil. Part I, Petrogenesis. Acta Geológica Leopoldensia, 17:35-152.

Silva L.C., Hartmann LA, McNaughton N.J., Fletcher I.R. 1997. SHRIMP U/Pb zircon dating of Neoproterozoic granitic magmatism and collision in the Pelotas batholith, southernmost Brazil. International Geology Review, 41:531-551.

Silva L.C., Hartmann LA, McNaughton N.J., Fletcher I.R. 2000. Zircon U/Pb SHRIMP dating of a Neoproterozoic overprint in Paleoproterozoic granitic-gneissic terranes, southern Brazil. American Mineralogist, 85:649-668.

Silva L.C., McNaughton N.J., Armstrong R., Hartmann L.A., Fletcher I.R. 2005. The Neoproterozoic Mantiqueira Province and its African connections, a zircon-based U-Pb geochronologic subdivision of the Brasiliano/PanAfrican systems of orogens. Precambrian Research, 136:203-240.

Simões M.S., Philipp R.P., Formoso M.L.L., Camozzato E. 2014 Geologia do Complexo Máfico-ultramáfico Mata Grande, São Sepé, RS, Pesquisas em Geociências, 41(2):105-120.

Soliani Jr. E. 1986. Os dados geocronológicos do Escudo Sul-riograndense e suas implicações de ordem geotectônica. Tese de Doutorado, Curso de Pós-Graduação em Geociências, Universidade de São Paulo, 425p, inédito.

Sommer C.A., Lima E.F., Nardi L.V.S., Figueiredo A.M.G., Pierosan R. 2005. Potassic and low- and high-Ti mildly alkaline volcanism in the Neoproterozoic Ramada Plateau, southernmost Brazil. Journal of South American Earth Sciences, 18(3):237-254.

Vasquez. 1997. Evolução petrogenética dos granitos da Suite Intrusiva Encruzilhada do Sul-RS. Dissertação de Mestrado, Instituto de Geociências, UFRGS, Porto Alegre, 195p.

Vedana L.A., Philipp R.P., Basei M.A.S. 2016. Geochemistry and provenance of the Pontas do Salso Complex, São Gabriel Terrane, Dom Feliciano Belt, southernmost Brazil. International Geology Review. In press.

Wildner W., Lima E.F., Nardi LV.S., Sommer C.A. 2002. Volcanic Cycles and Setting in the Neoproterozoic III to Ordovician Camaquã Basin Succession in Southern Brazil: Characteristics of Post-Collisional Magmatism. Journal of Volcanology and Geothermal Research, 118:261-283.

Available at www.sbgeo.org.br 